\title{
A Review of Sample Analysis at Mars-Evolved Gas Analysis Laboratory Analog Work Supporting the Presence of Perchlorates and Chlorates in Gale Crater, Mars
}

\author{
Joanna Clark ${ }^{1, *(\mathbb{D}}$, Brad Sutter ${ }^{2}$, P. Douglas Archer Jr. ${ }^{2}$, Douglas Ming ${ }^{3}$, Elizabeth Rampe ${ }^{3}$, Amy McAdam ${ }^{4}$, \\ Rafael Navarro-González ${ }^{5,+} \mathbb{D}$, Jennifer Eigenbrode ${ }^{4}\left(\mathbb{D}\right.$, Daniel Glavin ${ }^{4}$ (D), Maria-Paz Zorzano ${ }^{6,7}$ (D), \\ Javier Martin-Torres $^{7,8}$, Richard Morris ${ }^{3}$, Valerie Tu ${ }^{2}$, S. J. Ralston ${ }^{2} \mathbb{D}$ and Paul Mahaffy ${ }^{4}$
}

Citation: Clark, J.; Sutter, B.; Archer, P.D., Jr.; Ming, D.; Rampe, E.; McAdam, A.; Navarro-González, R.; Eigenbrode, J.; Glavin, D.; Zorzano, M.-P.; et al. A Review of Sample Analysis at Mars-Evolved Gas Analysis Laboratory Analog Work Supporting the Presence of Perchlorates and Chlorates in Gale Crater, Mars. Minerals 2021, 11, 475. https://doi.org/10.3390/min11050475

Academic Editor: Dominic Papineau

Received: 25 February 2021

Accepted: 22 April 2021

Published: 30 April 2021

Publisher's Note: MDPI stays neutral with regard to jurisdictional claims in published maps and institutional affiliations.

Copyright: (c) 2021 by the authors. Licensee MDPI, Basel, Switzerland. This article is an open access article distributed under the terms and conditions of the Creative Commons Attribution (CC BY) license (https:/ / creativecommons.org/licenses/by/ $4.0 /)$.
1 GeoControls Systems Inc-Jacobs JETS Contract at NASA Johnson Space Center, Houston, TX 77058, USA 2 Jacobs JETS Contract at NASA Johnson Space Center, Houston, TX 77058, USA; brad.sutter-2@nasa.gov (B.S.); doug.archer@nasa.gov (P.D.A.J.); valerie.m.tu@nasa.gov (V.T.); silas.ralston@nasa.gov (S.J.R.)

3 NASA Johnson Space Center, Houston, TX 77058, USA; douglas.w.ming@nasa.gov (D.M.); elizabeth.b.rampe@nasa.gov (E.R.); richard.v.morris@nasa.gov (R.M.)

4 NASA Goddard Space Flight Center, Greenbelt, MD 20771, USA; amy.mcadam-1@nasa.gov (A.M.); jennifer.l.eigenbrode@nasa.gov (J.E.); daniel.p.glavin@nasa.gov (D.G.); paul.r.mahaffy@nasa.gov (P.M.)

5 Institito de Ciencias Nucleares, Universidad Nacional Autonoma de Mexico, Mexico City 04510, Mexico; navarro@nucleares.unam.mx

6 Centro de Astrobiología (INTA-CSIC), Torrejon de Ardoz, 28850 Madrid, Spain; zorzanomm@cab.inta-csic.es

7 Department of Planetary Sciences, School of Geosciences, University of Aberdeen, Aberdeen AB24 3FX, UK; javier.martin-torres@abdn.ac.uk

8 Instituto Andaluz de Ciencias de la Tierra (CSIC-UGR), Armilla, 18100 Granada, Spain

* Correspondence: joanna.v.clark@nasa.gov

+ Deceased 28 January 2021.

\begin{abstract}
The Sample Analysis at Mars (SAM) instrument on the Curiosity rover has detected evidence of oxychlorine compounds (i.e., perchlorates and chlorates) in Gale crater, which has implications for past habitability, diagenesis, aqueous processes, interpretation of in situ organic analyses, understanding the martian chlorine cycle, and hazards and resources for future human exploration. Pure oxychlorines and mixtures of oxychlorines with Mars-analog phases have been analyzed for their oxygen $\left(\mathrm{O}_{2}\right)$ and hydrogen chloride $(\mathrm{HCl})$ releases on SAM laboratory analog instruments in order to constrain which phases are present in Gale crater. These studies demonstrated that oxychlorines evolve $\mathrm{O}_{2}$ releases with peaks between $\sim 200$ and $600{ }^{\circ} \mathrm{C}$, although the thermal decomposition temperatures and the amount of evolved $\mathrm{O}_{2}$ decrease when iron phases are present in the sample. $\mathrm{Mg}$ and Fe oxychlorines decompose into oxides and release $\mathrm{HCl}$ between $\sim 200$ and $542{ }^{\circ} \mathrm{C}$. $\mathrm{Ca}, \mathrm{Na}$, and $\mathrm{K}$ oxychlorines thermally decompose into chlorides and do not evolve $\mathrm{HCl}$ by themselves. However, the chlorides (original or from oxychlorine decomposition) can react with water-evolving phases (e.g., phyllosilicates) in the sample and evolve $\mathrm{HCl}$ within the temperature range of SAM $\left(<\sim 870{ }^{\circ} \mathrm{C}\right)$. These laboratory analog studies support that the SAM detection of oxychlorine phases is consistent with the presence of $\mathrm{Mg}, \mathrm{Ca}, \mathrm{Na}$, and $\mathrm{K}$ perchlorate and/or chlorate along with possible contributions from adsorbed oxychlorines in Gale crater samples.
\end{abstract}

Keywords: perchlorates; chlorates; oxychlorines; chlorides; Sample Analysis at Mars; Curiosity Gale crater; evolved gas analysis; MSL

\section{Introduction}

The Mars Science Laboratory (MSL) Curiosity rover landed in Gale crater, Mars on 6 August 2012 and has traversed $\sim 23 \mathrm{~km}$ of sedimentary strata as of sol 2991 (January 2021). Gale crater is a $154 \mathrm{~km}$ diameter crater that formed $\sim 3.6$ to $3.8 \mathrm{Ga}$ on sloping terrain $\left(\sim 5^{\circ} \mathrm{S}, 138^{\circ} \mathrm{E}\right)$ between the Noachian southern highlands and the Hesperian lowlands $[1,2]$ (Figure 1). The crater and surrounding plains possess orbital geomorphological evidence 
of fluvial activity such as valley networks and an alluvial fan [1]. Gale crater has an interior mound, informally called "Mt. Sharp", that is over $5 \mathrm{~km}$ above the elevation of the Bradbury landing site [3]. Since its landing, Curiosity has explored hundreds of vertical meters of layered sedimentary rocks containing minerals indicative of past aqueous conditions including phyllosilicates and sulfates.

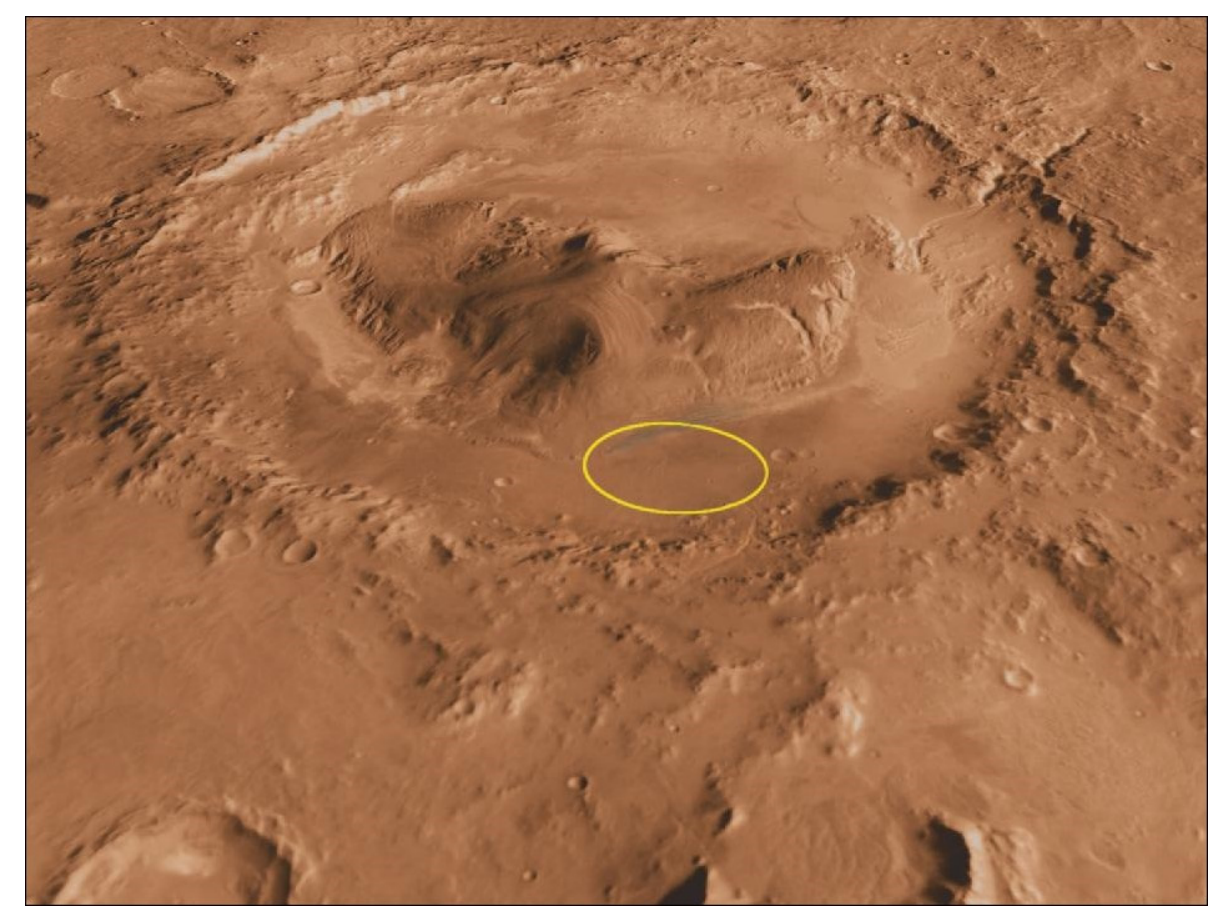

Figure 1. Image showing Gale crater $(\sim 154 \mathrm{~km}$ diameter) and the landing ellipse in yellow. The image was created using combined data from the Thermal Emission Imaging System camera on the Mars Odyssey orbiter, the Mars Orbiter Laser Altimeter on the Mars Global Surveyor orbiter, and the High-Resolution Imaging Science Experiment camera on the Mars Reconnaissance Orbiter. Image credit: NASA/JPL-Caltech/ASU/UA.

The primary goal of the Curiosity rover was to characterize the geology and chemistry of the martian surface in Gale crater in order to determine whether it was ever habitable for microbial life. Curiosity has accomplished this goal by characterizing martian surface geology and chemistry using several scientific instruments, some of which intake solid sample that is either scooped or drilled from the surface. One of the important findings from Curiosity has been the detection of the volatile decomposition products of perchlorates $\left(\mathrm{ClO}_{4}{ }^{-}\right)$and chlorates $\left(\mathrm{ClO}_{3}{ }^{-}\right)$, hereon called "oxychlorines", in Gale crater surface materials by the Sample Analysis at Mars (SAM) instrument. The presence of oxychlorines on Mars has implications for past habitability, diagenesis, aqueous processes, future in situ organic analysis strategies, and hazards and resources for future human exploration.

The presence of oxychlorines in Gale crater was supported by data collected from the SAM instrument on Curiosity in conjunction with laboratory analog work. Laboratory SAM evolved gas analysis (EGA) analog experiments are essential for understanding the complex datasets from SAM because they utilize minerals and phases (e.g., oxychlorines, phyllosilicates) with precisely known compositions and chemistries. Additionally, experimental parameters (e.g., furnace pressure, carrier gas, temperature ramp rate) can affect the results from evolved gas analyses, making it especially important to analyze Mars-analog phases under the same operating conditions as SAM in order for the results to be relevant to SAM data from Curiosity. This paper provides a background for the detection of oxychlorines on Mars and reviews the SAM-EGA laboratory analog work that supports the presence of oxychlorines in Gale crater and provides constraints on their speciation. 


\section{Background}

\subsection{Oxychlorines on Earth}

Terrestrial perchlorates can occur naturally and from anthropogenic sources. Perchlorates have been used as an oxidant in rockets, air bags, pyrotechnics, and other manufactured products, and as a result have been detected in ground and surface water, soils, and plants $[4,5]$. Anthropogenic perchlorate can also originate from $\mathrm{NO}_{3}{ }^{-}$-rich caliche salts that are often used in fertilizers [6]. Oxychlorines also occur naturally on the Earth's surface, although they are rare, and are often found in extremely arid environments such as the Atacama Desert, West Texas, and the Antarctic Dry Valleys (e.g., [4,5,7-10]). The Atacama Desert has the most Mars-like concentration of natural perchlorate, which can be as high as $\sim 0.6 \mathrm{wt} . \%$ in veins in nitrate ores [11]. Other locations such as West Texas, the Antarctic Dry Valleys, the Bolivian playas, central Canada, and New Mexico have much lower concentrations of perchlorates compared to the Atacama Desert (< 0.004 wt. \%; $[4,7,8,12,13]$. Chlorates have been reported in comparable concentrations in terrestrial soils such as the Atacama Desert; Death Valley, California; the Amargosa Desert, Nevada; Antarctica; and Namibia, Africa (e.g., [9,12]).

\subsection{Detection of Oxychlorines on Mars}

\subsubsection{Phoenix Wet Chemistry Lab}

The first in situ detection of perchlorates on Mars came from the Wet Chemistry Lab (WCL) on board the Phoenix spacecraft, which landed in the northern polar region in 2008 [13]. The WCL utilized ion-selective electrodes (ISE) to analyze the solution chemistry of excavated icy regolith [13]. The ISE that was originally intended to detect nitrate $\left(\mathrm{NO}_{3}{ }^{-}\right)$produced a signal too intense to be attributed to nitrate alone, and Hecht et al. [13] concluded that this was due to the presence of perchlorate in the soil because the ISE was three times more sensitive to perchlorate than nitrate. The presence of chlorate was also plausible because the ISE sensitivity to chlorate was similar to nitrate, both of which would be overwhelmed by the perchlorate signal [14]. The distribution of cations as detected by the WCL in addition to laboratory analog experiments suggested that $\mathrm{Ca}$ and $\mathrm{Mg}$ perchlorate were the dominant perchlorates present at the landing site $[13,15]$.

\subsubsection{Phoenix Thermal and Evolved Gas Analyzer}

Soils analyzed by the Thermal and Evolved Gas Analyzer (TEGA) instrument independently supported the presence of oxychlorine species at the Phoenix landing site [13]. The TEGA instrument consisted of eight ovens which heated icy soil samples that were scooped from trenches surrounding the lander $[16,17]$. Gases evolved during sample heating were then sent to a mass spectrometer for identification. The type of gas and the timing of its evolution were used to identify volatile-bearing minerals and phases in the sample [17]. The Baby Bear surface sample analyzed by TEGA produced oxygen releases ranging from 325 to $625^{\circ} \mathrm{C}$, which supported the presence of oxychlorines at the Phoenix landing site [13].

\subsubsection{Viking Landers}

A study by Navarro-González et al. [18] re-evaluated thermal volatilization-gas chromatography-mass spectrometry (TV-GC-MS) data from the Viking landers in response to the discovery of perchlorates at the Phoenix landing site and demonstrated that the detected chlorohydrocarbons could be the products of indigenous organics reacting with perchlorates during sample heating. The Viking landers arrived in Chryse Planitia and Utopia Planitia, Mars in 1976 and each analyzed two basaltic regolith samples (i.e., martian soil) using TV-GC-MS with the goal of finding organic compounds $[19,20]$. Both Viking landers detected chlorohydrocarbons, but these were thought to be terrestrial contaminants from the solvents used to clean the instruments because they were not expected as the major organic group and the ${ }^{37} \mathrm{Cl} /{ }^{35} \mathrm{Cl}$ ratios in the chlorohydrocarbons were similar to those on Earth [19-21]. The Navarro-González et al. [18] study demonstrated that perchlorates could react with organics in sediment samples during heating, causing the release of $\mathrm{CO}_{2}$ 
(combustion) and formation of chlorohydrocarbons (chlorination). The results from this study suggested that the chlorohydrocarbons detected by the Viking landers may have been the result of organic matter indigenous to the martian soil reacting with perchlorates during sample heating.

\subsubsection{Curiosity Rover's Sample Analysis at Mars Instrument}

The SAM instrument on the Curiosity rover serves to characterize the isotopic and chemical composition of the martian atmosphere and volatile-bearing phases in Gale crater surface materials with the goal of understanding past environmental conditions and habitability [22]. Up until sol 1536 (November 2016) drilled or scooped samples were delivered by the rover's Collection and Handling for In Situ Martian Rock Analysis (CHIMRA) device to cups inside SAM's Sample Manipulation System (SMS), where they were then transferred into one of SAM's ovens for heating. After a drill anomaly on sol 1536, rock targets were drilled using a process called "feed extended drilling", or FED, where the drill was fully extended past the stabilizers and the rover's arm was used to extend and retract the drill bit from the rock target [23]. Samples were then fed directly into the SAM inlet by reversing the spin direction of the drill bit while positioned over the inlet [23]. This new process, called "feed-extended sample transfer", or FEST, did not require the use of CHIMRA. Solid samples were heated from 35 to $\sim 870{ }^{\circ} \mathrm{C}$ at a rate of $\sim 35^{\circ} \mathrm{C} / \mathrm{min}$ [22,24-26]. Volatilebearing phases (e.g., phyllosilicates, oxychlorines) thermally decompose and evolve gases (e.g., $\mathrm{H}_{2} \mathrm{O}, \mathrm{SO}_{2}, \mathrm{O}_{2}, \mathrm{HCl}$ ) at characteristic temperatures, which through a He carrier gas (30 mbar, $0.8 \mathrm{sccm}$ ) were sent to a quadrupole mass spectrometer (QMS) via a capillary leak for EGA. The unsampled split of evolved gases were then either directed to enrich volatiles on a hydrocarbon trap prior to gas chromatography-mass spectrometry (GC-MS) analysis or sent to the tunable laser spectrometer (TLS).

\subsubsection{SAM Detection of Oxychlorines}

Oxychlorine compounds were inferred to be present in the first sample analyzed by the SAM instrument called Rocknest, which was scooped from an inactive, dust covered sand shadow on sol 84 (October 2012; Figure 2) [24,25,27]. SAM-EGA detected an $\mathrm{O}_{2}$ release with a peak at $\sim 380-390{ }^{\circ} \mathrm{C}$ and a high-temperature $\left(>600{ }^{\circ} \mathrm{C}\right) \mathrm{HCl}$ release, which were consistent with the thermal decomposition of oxychlorines [27]. SAM's GC-MS mode detected chlorinated hydrocarbons at the same temperature as the $\mathrm{O}_{2}$ evolution observed in EGA data, providing further evidence for the presence of perchlorates or chlorates in Rocknest [25]. Rocknest fines $(<150 \mu \mathrm{m})$ contained $0.3-0.5 \mathrm{wt} . \% \mathrm{ClO}_{4}{ }^{-}$, assuming all evolved $\mathrm{O}_{2}$ resulted from oxychlorine thermal decomposition [24]. 


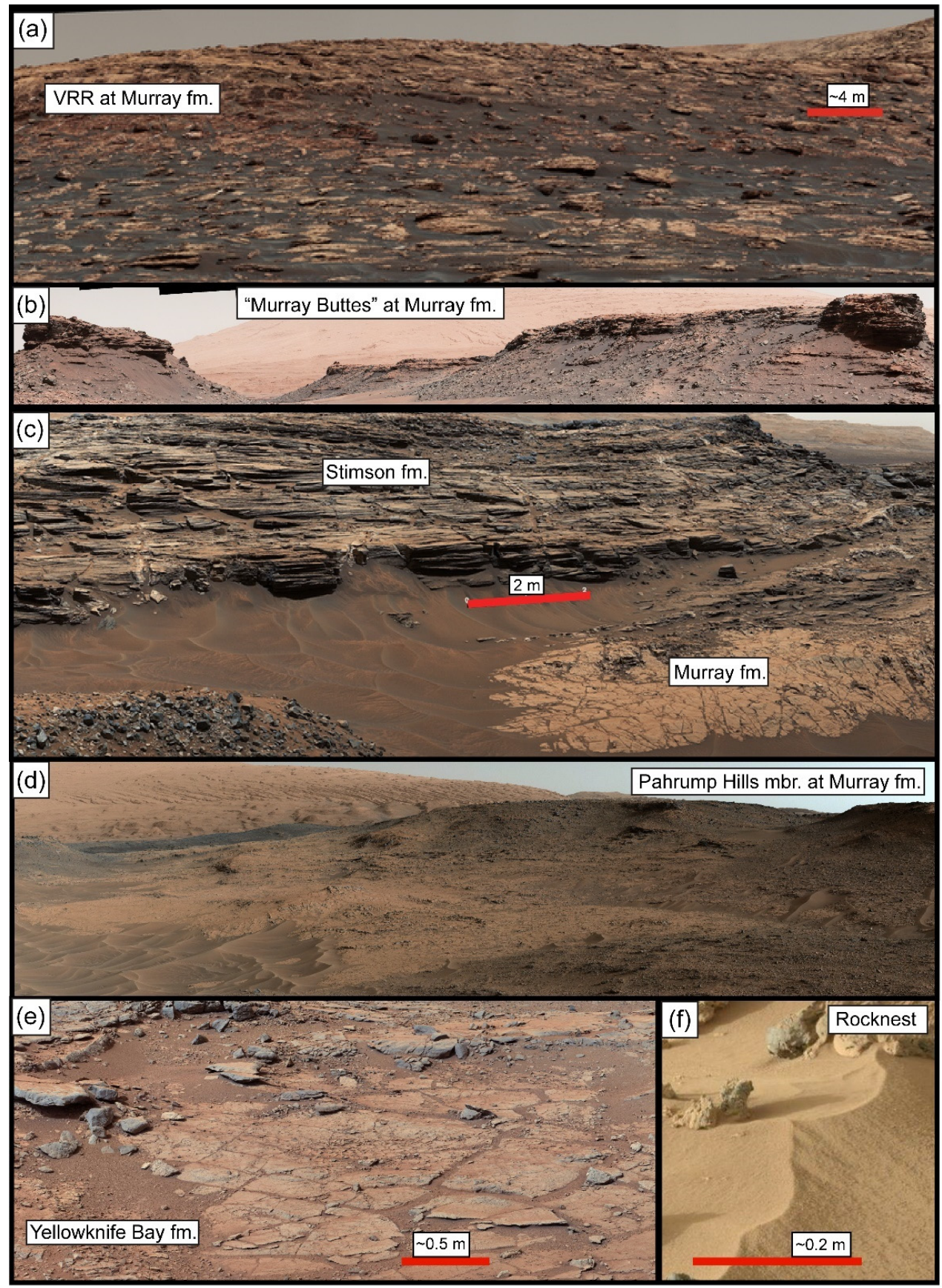

Figure 2. Mast Camera (Mastcam) images depicting some of the diverse environments sampled by Curiosity. (a) Mastcam mosaic of the Vera Rubin Ridge (VRR) in the Murray formation combining images acquired on sol 1734 (June 2017). Stoer, Rock Hall, and Highfield were sampled on the VRR. (b) Image of the "Murray Butte" region of the Murray formation acquired on sol 1434 (August 2016), where Marimba and Quela were sampled by Curiosity. The top of the left butte is $\sim 8 \mathrm{~m}$ above the surrounding plain, for scale. (c) Mastcam mosaic combining images acquired on sol 992 (May 2015), showing large-scale crossbedding on the Stimson formation, where Big Sky and Greenhorn were sampled. (d) Mastcam images acquired on sol 751 (September 2014) of the Pahrump Hills member of the Murray formation, where Confidence Hills, Mojave, Telegraph Peak, and Buckskin were sampled. Image was taken $\sim 20 \mathrm{~m}$ from the Pahrump Hills outcrop, where $\sim 18 \mathrm{~m}$ of strata was exposed. (e) Mastcam image acquired on sol 138 (December 2012) of the Yellowknife Bay formation where Cumberland and John Klein were sampled. (f) Mastcam image of a wind-blown deposit where the Rocknest sample was scooped on sol 84 (October 2012). Image credit: NASA/JPL. 
Evolved oxygen, $\mathrm{HCl}$, and chlorohydrocarbons, indicative of oxychlorines, were detected in subsequently analyzed samples in a variety of depositional environments (e.g., lacustrine, aeolian) recorded in the Yellowknife Bay, Stimson, Kimberley, and Murray formations observed over an elevation change of $\sim 380 \mathrm{~m}$ (Figures 2 and 3) [26,28,29]. $\mathrm{O}_{2}$ release peak temperatures attributed to oxychlorines ranged from $\sim 250$ to $600{ }^{\circ} \mathrm{C}$ [26] (Figure 4; Table 1). Oxychlorine concentrations were as high as $1.05 \mathrm{wt} . \%$ in the Yellowknife Bay formation, but some of the Vera Rubin Ridge (VRR) samples produced no evidence of oxychlorines, possibly due to leaching of soluble salts [28-30]. Samples that did not evolve $\mathrm{O}_{2}$ but did evolve $\mathrm{HCl}$ (Oudam, Marimba, Quela, Duluth, Stoer, Highfield) may contain chlorides $[29,30]$. The presence of multiple $\mathrm{O}_{2}$ peaks in some samples such as Big Sky and Greenhorn suggested that multiple cation phases of perchlorates and/or chlorates were present (Figure 4) [26,31].

Table 1. $\mathrm{O}_{2}$ and $\mathrm{HCl}$ release peak temperatures from Gale crater samples and possible oxychlorines or chlorides present. Oxychlorines were considered possible candidates for $\mathrm{O}_{2}$ production in SAM samples if the sample's $\mathrm{O}_{2}$ release occurred at or below the $\mathrm{O}_{2}$ release peak of the pure oxychlorine as analyzed in the laboratory under SAM-like conditions. $\mathrm{Mg}$ oxychlorines were considered possible candidates for $\mathrm{O}_{2}$ and $\mathrm{HCl}$ production in SAM samples if the sample's $\mathrm{O}_{2}$ and $\mathrm{HCl}$ releases occurred at or below the peaks of pure $\mathrm{Mg}$ oxychlorines as analyzed in the lab. Samples that evolved $\mathrm{HCl}$ but no $\mathrm{O}_{2}$ likely contained chlorides, which can react with water to produce high-temperature $\mathrm{HCl}$ [29].

\begin{tabular}{|c|c|c|c|}
\hline Sample & $\mathrm{O}_{2}$ Release Peak $\left({ }^{\circ} \mathrm{C}\right)$ & HCl Release Peak $\left({ }^{\circ} \mathrm{C}\right)$ & Possible Oxychlorines Present \\
\hline Rocknest & 377 & 749 & $\mathrm{Na}$, K, Ca perchlorate; $\mathrm{Na}, \mathrm{K}$, Ca chlorate \\
\hline Gobabeb 2 & 373 & 763 & $\mathrm{Na}, \mathrm{K}, \mathrm{Ca}$ perchlorate; $\mathrm{Na}, \mathrm{K}$, Ca chlorate \\
\hline John Klein & 368 & 749 & $\mathrm{Na}, \mathrm{K}$, Ca perchlorate; $\mathrm{Na}, \mathrm{K}$, Ca chlorate \\
\hline Cumberland & 313 & 347,728 & $\begin{array}{c}\mathrm{Na}, \mathrm{K}, \mathrm{Ca}, \mathrm{Mg} \text { perchlorate; } \mathrm{Na}, \mathrm{K}, \mathrm{Ca}, \mathrm{Mg} \text { chlorate } \\
\text { likely contains } \mathrm{Mg} \text { oxychlorines }\end{array}$ \\
\hline Windjana & 418 & 682 & $\mathrm{Na}, \mathrm{K}$, Ca perchlorate; $\mathrm{Na}, \mathrm{K}$ chlorate \\
\hline Confidence Hills & 568 & 655,807 & $\mathrm{Na}, \mathrm{K}$ perchlorate \\
\hline Mojave & 415 & 640,827 & $\mathrm{Na}, \mathrm{K}$, Ca perchlorate; $\mathrm{Na}$, K chlorate \\
\hline Telegraph Peak & 403 & 574 & $\mathrm{Na}, \mathrm{K}, \mathrm{Ca}$ perchlorate; $\mathrm{Na}, \mathrm{K}$ chlorate \\
\hline Buckskin & 410 & 688 & $\mathrm{Na}, \mathrm{K}$, Ca perchlorate; $\mathrm{Na}, \mathrm{K}$ chlorate \\
\hline Oudam & none & 722 & chlorides \\
\hline Big Sky & 364,478 & $365,493,836$ & $\mathrm{Na}, \mathrm{K}, \mathrm{Ca}, \mathrm{Mg}$ perchlorate; $\mathrm{Na}, \mathrm{K}, \mathrm{Ca}, \mathrm{Mg}$ chlorate \\
\hline Greenhorn & $257,345,427$ & 714 & $\mathrm{Na}, \mathrm{K}, \mathrm{Ca}$ perchlorate; $\mathrm{Na}, \mathrm{K}, \mathrm{Ca}$ chlorate \\
\hline Marimba & none & 839 & chlorides \\
\hline Quela & none & 634,731 & chlorides \\
\hline Duluth & none & 700 & chlorides \\
\hline Stoer & none & 613 & chlorides \\
\hline Highfield & none & 823 & chlorides \\
\hline Rock Hall & 301 & 825 & $\mathrm{Na}$, K, Ca perchlorate; $\mathrm{Na}, \mathrm{K}$, Ca chlorate \\
\hline
\end{tabular}

Chlorine isotopes measured by SAM's QMS have also been suggested as evidence for the presence of oxychlorines in Gale crater [32]. Most terrestrial materials have little variation in $\mathrm{Cl}$ isotopic composition ( $\pm 3 \%$ ) [33-35], although perchlorates in the Atacama Desert have $\mathrm{Cl}$ isotopic compositions as low as $-15 \%$ due to perchlorate's unique ability to strongly fractionate $\mathrm{Cl}$ isotopes $[5,36]$. Chlorine isotopic compositions in Gale crater range from $-1 \pm 25 \%$ to $-51 \pm 5 \%$ [32]. The unusually light and variable $\mathrm{Cl}$ isotopic compositions suggest that perchlorate may be a source of $\mathrm{HCl}$ in many Gale crater samples [32]. Differences in $8^{37} \mathrm{Cl}$ would not correspond to differences in $\mathrm{HCl}$ evolution temperature because the $\mathrm{HCl}$ evolution temperature varies depending on other phases present in the sample, even with a single $\mathrm{Cl}$ source [37]. 


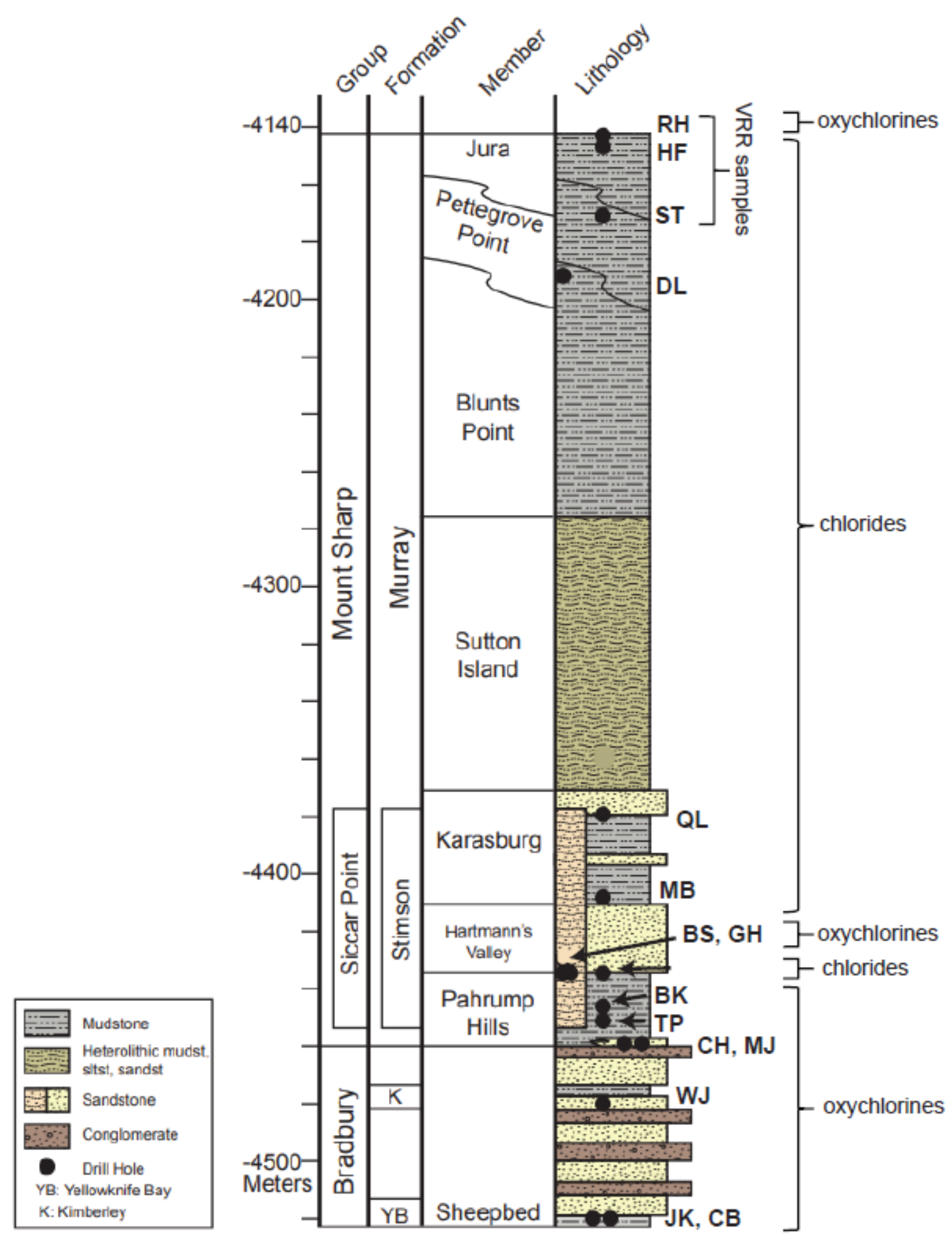

Figure 3. Stratigraphic column showing lithology, approximate elevation, and presence of oxychlorines or chlorides in drill holes analyzed by SAM. Oxychlorine and chloride brackets represent their detection in individual drilled samples, and not necessarily at unsampled locations in between. Scooped samples (Rocknest and Gobabeb) are not included in this figure. Modified from MSL Sed/Strat working group. Abbreviations: JK = John Klein, CB = Cumberland, WJ = Windjana, $\mathrm{CH}=$ Confidence Hills, MJ = Mojave, $\mathrm{TP}=$ Telegraph Peak, BK = Buckskin, BS = Big Sky, OU = Oudam, GH = Greenhorn, $\mathrm{MB}=$ Marimba, $\mathrm{QL}=$ Quela, $\mathrm{DU}=$ Duluth, $\mathrm{ST}=$ Stoer, $\mathrm{KM}=$ Kilmarie, HF $=$ Highfield, $\mathrm{RH}=$ Rock Hall, and VRR $=$ Vera Rubin Ridge. 


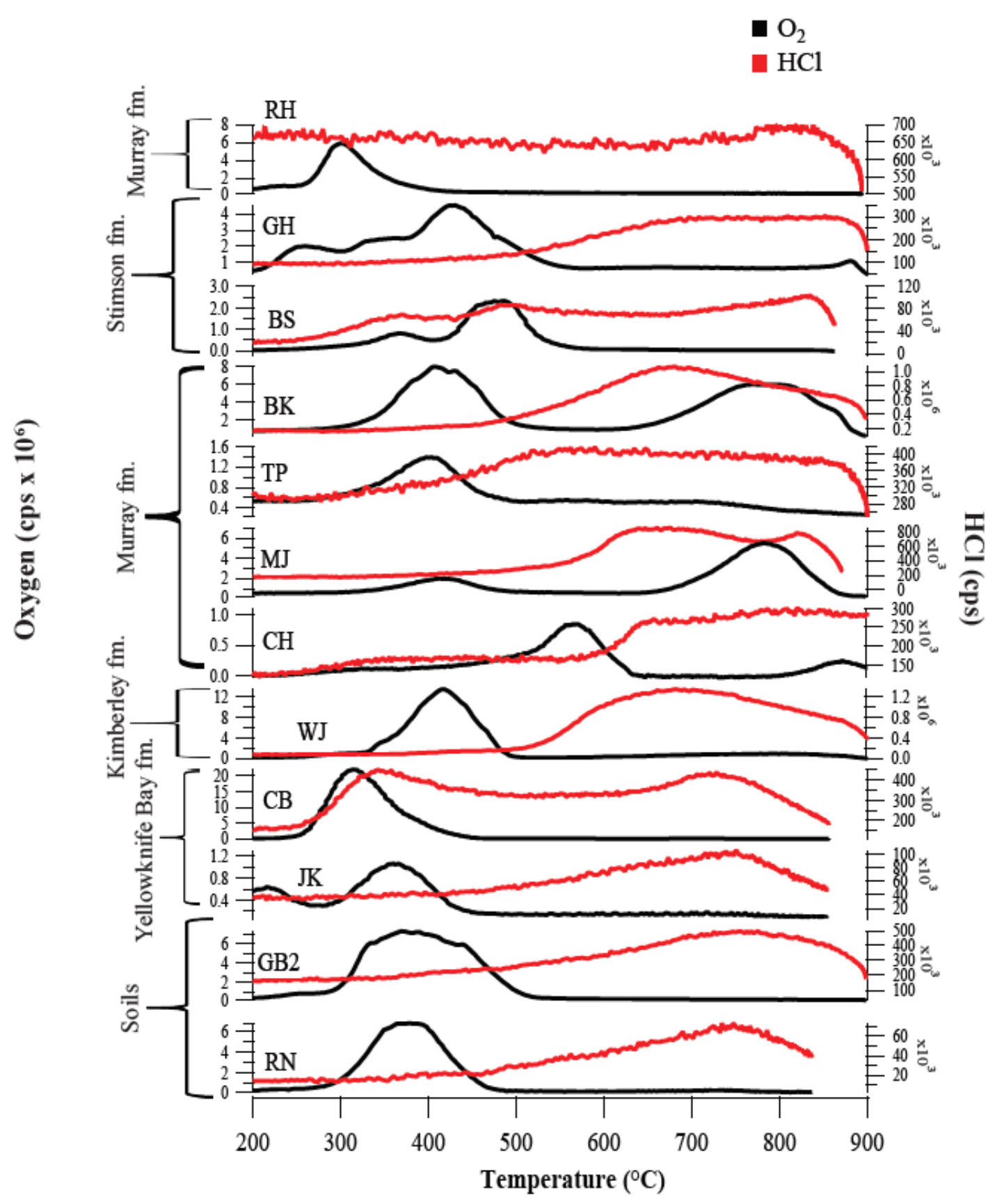

Figure 4. Evolved $\mathrm{O}_{2}(\mathrm{~m} / \mathrm{z}$ 32) and $\mathrm{HCl}(\mathrm{m} / \mathrm{z}$ 36) profiles measured by the SAM QMS in counts/sec (cps) during pyrolysis of Gale crater samples. Samples that did not evolve $\mathrm{O}_{2}$ are not included in this figure. Abbreviations: $\mathrm{RN}=\mathrm{Rocknest}$, GB2 = Gobabeb2, JK = John Klein, CB = Cumberland, WJ = Windjana, CH = Confidence Hills, MJ = Mojave, TP = Telegraph Peak, BK = Buckskin, BS = Big Sky, GH = Greenhorn, and RH = Rock Hall. Samples (with the exception of the soils) are ordered stratigraphically, with the stratigraphically lowest sample on the bottom.

\subsubsection{Orbital Spectral Detections of Oxychlorines}

In addition to landed Mars missions, the Compact Reconnaissance Imaging Spectrometer for Mars (CRISM) on the Mars Reconnaissance Orbiter (MRO) detected spectral features consistent with hydrated oxychlorine salts on recurring slope lineae (RSL) [38]. Seasonal brine flows of hydrated salts have been proposed as an explanation for the formation of RSL's due to their low eutectic points and hygroscopic nature [39]. Spectral data were most consistent with the presence of $\mathrm{Mg}$ perchlorate, $\mathrm{Mg}$ chlorate, and Na perchlorate [38]. However, subsequent studies showed that absorptions attributed to perchlorate salts could 
be an artifact from a filtering step in CRISM data processing [40]. Ongoing studies showed that CRISM spectral features in Columbus crater were consistent with chlorine salts, including oxychlorines, and were not affected by the artifact described in Leask et al. [40,41]. Spectral detection of oxychlorines remains difficult due to data processing artifacts and interferences by minerals with similar absorptions.

\subsubsection{Oxychlorine Detections in Martian Meteorites}

Perchlorates and chlorates have also been detected in martian meteorites [42,43]. Con-

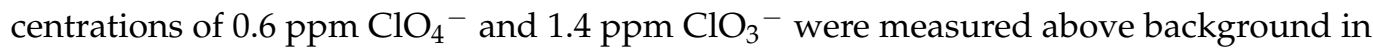
extracts of the martian meteorite EETA79001 using ion chromatography (IC). Terrestrial contamination was excluded as an explanation due to the location of the sample within the meteorite and isotopic ratios [42]. Lower concentrations of $\mathrm{ClO}_{4}{ }^{-}$were reported in the other martian meteorite [44], and terrestrial contamination was also excluded due to dissimilarities between the soluble geochemistry of the Tissint meteorite and the surrounding soil in its strewn field [43].

\section{Review of SAM-EGA Laboratory Analog Work Supporting the Presence of Oxychlorines in Gale Crater, Mars \\ 3.1. Perchlorates}

Mid-temperature $\mathrm{O}_{2}$ releases between $\sim 200$ and $600{ }^{\circ} \mathrm{C}$ in SAM-EGA data were attributed to the presence of oxychlorines, prompting the need for laboratory SAM-analog analyses to constrain the types of perchlorates present in Gale crater samples. The thermal decomposition of perchlorates has long been studied and has provided an important basis for the study of perchlorates using SAM-analog instruments [45-47]. However, experimental parameters such as furnace pressure and heating rate can alter the decomposition temperature, making it important to analyze perchlorates under SAM-like conditions. Perchlorates with different cations (e.g., $\mathrm{Mg}$, Fe, $\mathrm{Na}, \mathrm{K}, \mathrm{Ca}$ ) were individually analyzed using laboratory EGA instruments configured to operate similarly to SAM (30 mbar He, $35^{\circ} \mathrm{C} / \mathrm{min}$ heating rate), and results were compared to SAM-EGA data from Mars. Different flow rates were used to account for volume differences between the SAM oven and the furnaces on the laboratory analytical instruments; however, the minor differences in flow rate should not have a significant impact on the EGA results.

The mechanism, thermal decomposition products, and decomposition temperatures of perchlorates under SAM-like conditions were dependent upon the cation. Mg perchlorate thermally decomposed into $\mathrm{MgO}$ and evolved $\mathrm{O}_{2}$ and $\mathrm{Cl}_{2}$ (reaction 1 ). The $\mathrm{Cl}_{2}$ then reacted with water from the hydrated perchlorate to produce $\mathrm{HCl}$ [45-48] (reactions 1 and 2). The $\mathrm{O}_{2}$ and $\mathrm{HCl}$ releases from $\mathrm{Mg}$ perchlorate peaked at $\sim 540{ }^{\circ} \mathrm{C}$ (Table 2) [29].

$$
\begin{gathered}
2 \mathrm{Mg}\left(\mathrm{ClO}_{4}\right)_{2} \cdot x \mathrm{H}_{2} \mathrm{O} \rightarrow 2 \mathrm{MgO}+2 \mathrm{Cl}_{2}+7 \mathrm{O}_{2}+x \mathrm{H}_{2} \mathrm{O} \\
x \mathrm{H}_{2} \mathrm{O}+x \mathrm{Cl}_{2} \rightarrow 2 x \mathrm{HCl}+x / 2 \mathrm{O}_{2}
\end{gathered}
$$

Fe perchlorates exhibited $4-5 \mathrm{O}_{2}$ release peaks ranging from $\sim 90$ to $280{ }^{\circ} \mathrm{C}$ and also decomposed into oxides [25,45].

$\mathrm{Na}, \mathrm{K}$, and Ca perchlorate thermally decomposed into chlorides and evolved $\mathrm{O}_{2}$ with peaks at 578, $\sim 600$, and $486^{\circ} \mathrm{C}$, respectively (reactions 3-5; Table 2) Na, K, and Ca perchlorate did not evolve $\mathrm{HCl}$ release peaks within the temperature range of SAM $[45,49,50]$. However, some studies suggested that $\mathrm{Ca}$ perchlorate starts to evolve $\mathrm{HCl}$ at the high end of the SAM temperature range due to reactions with water [25].

$$
\begin{gathered}
\mathrm{NaClO}_{4} \rightarrow \mathrm{NaCl}+2 \mathrm{O}_{2} \\
\mathrm{KClO}_{4} \rightarrow \mathrm{KCl}+2 \mathrm{O}_{2} \\
\mathrm{Ca}\left(\mathrm{ClO}_{4}\right)_{2} \rightarrow \mathrm{CaCl}_{2}+4 \mathrm{O}_{2}
\end{gathered}
$$


Table 2. $\mathrm{O}_{2}$ and $\mathrm{HCl}$ release peak temperatures from perchlorates and chlorates analyzed in the laboratory under SAM-like conditions. $\mathrm{n} / \mathrm{a}=$ no release detected within the temperature range of SAM.

\begin{tabular}{cccc}
\hline Oxychlorine & $\begin{array}{c}\mathbf{O}_{2} \text { Release Peak } \\
\text { Temperature }\left({ }^{\circ} \mathbf{C}\right)\end{array}$ & $\begin{array}{c}\text { HCl Release Peak } \\
\text { Temperature }\left({ }^{\circ} \mathbf{C}\right)\end{array}$ & Reference \\
\hline $\mathrm{Mg}\left(\mathrm{ClO}_{4}\right)_{2}$ & 542 & 542 & {$[29]$} \\
$\mathrm{Fe}(\mathrm{III})\left(\mathrm{ClO}_{4}\right)_{2}$ & $\sim 90,170,205,280$ & No data & {$[25]$} \\
$\mathrm{Fe}(\mathrm{II})\left(\mathrm{ClO}_{4}\right)_{2}$ & $\sim 140,205,277$ & $\mathrm{No} \mathrm{data}$ & {$[29]$} \\
$\mathrm{NaClO}_{4}$ & 578 & $\mathrm{n} / \mathrm{a}$ & {$[51]$} \\
$\mathrm{KClO}_{4}$ & $\sim 600$ & $\mathrm{n} / \mathrm{a}$ & {$[52]$} \\
$\mathrm{Ca}\left(\mathrm{ClO}_{4}\right)_{2}$ & 486 & 379 & {$[31]$} \\
$\mathrm{Mg}\left(\mathrm{ClO}_{3}\right)_{2}$ & 377 & $\mathrm{n} / \mathrm{a}$ & {$[53]$} \\
$\mathrm{Ca}\left(\mathrm{ClO}_{3}\right)_{2}$ & $\sim 400$ & $\mathrm{n} / \mathrm{a}$ & {$[31]$} \\
$\mathrm{NaClO}_{3}$ & 469 & $\mathrm{n} / \mathrm{a}$ & {$[31]$} \\
$\mathrm{KClO}_{3}$ & 482 & & {[}
\end{tabular}

Laboratory analog SAM-EGA results demonstrated that with a few exceptions, perchlorates evolved $\mathrm{O}_{2}$ at temperatures too high to explain most Gale crater $\mathrm{O}_{2}$ detections [24,54]. While not perfect matches, evolved $\mathrm{O}_{2}$ temperatures from $\mathrm{Fe}$ and $\mathrm{Mg}$ perchlorate closely resembled the $\mathrm{O}_{2}$ release temperatures of samples collected at Yellowknife Bay including John Klein and Cumberland [54]. Additionally, no perchlorates fully explained the $\mathrm{HCl}$ releases observed in Gale crater samples. Thus, chlorates were investigated as another possible source of the $\mathrm{O}_{2}$ and $\mathrm{HCl}$ releases detected in Gale crater samples.

\subsection{Chlorates}

Analyses of pure chlorates using SAM-EGA analog instrumentation demonstrated that chlorates thermally decompose similarly to their perchlorate counterparts, but usually at lower temperatures $[31,53]$. $\mathrm{Na}, \mathrm{K}$, and $\mathrm{Ca}$ chlorate decomposed into chlorides and evolved $\mathrm{O}_{2}$ releases with peaks between $\sim 400$ and $482{ }^{\circ} \mathrm{C}$ (e.g., reaction 6; Table 2) [55-57], whereas $\mathrm{Mg}$ and $\mathrm{Fe}$ chlorate decomposed into oxides and evolved $\mathrm{O}_{2}$ and $\mathrm{HCl}$ between $\sim 90$ and $379^{\circ} \mathrm{C}$ (e.g., reactions 7 and 8; Table 2) [25,31,53]. $\mathrm{Mg}, \mathrm{Ca}$, and Fe chlorates are especially hygroscopic and evolve low-temperature $\left(<200^{\circ} \mathrm{C}\right)$ water if not dehydrated prior to thermal and evolved gas analysis.

$$
\begin{gathered}
2 \mathrm{KClO}_{3} \rightarrow 2 \mathrm{KCl}+3 \mathrm{O}_{2} \\
2 \mathrm{Mg}\left(\mathrm{ClO}_{3}\right)_{2} \cdot x \mathrm{H}_{2} \mathrm{O} \rightarrow 2 \mathrm{MgO}+2 \mathrm{Cl}_{2}+5 \mathrm{O}_{2}+x \mathrm{H}_{2} \mathrm{O} \\
x \mathrm{H}_{2} \mathrm{O}+\mathrm{xCl} l_{2} \rightarrow 2 x \mathrm{HCl}+x / 2 \mathrm{O}_{2}
\end{gathered}
$$

Although pure chlorates evolved $\mathrm{O}_{2}$ at lower temperatures than their perchlorate counterparts, the $\mathrm{O}_{2}$ release peak temperatures were still higher than many $\mathrm{O}_{2}$ releases observed in SAM data from Gale crater samples. Additionally, the $\mathrm{HCl}$ releases from chlorates did not fully explain the $\mathrm{HCl}$ releases observed in the SAM data.

\subsection{Effects of Mars-Analog Phases on Oxychlorine $\mathrm{O}_{2}$ and $\mathrm{HCl}$ Releases}

3.3.1. Iron-Bearing Phases

The $\mathrm{O}_{2}$ releases from most perchlorates and chlorates occurred at higher temperatures than those observed in data collected by SAM, which led to the suggestion that other phases in Gale crater samples may catalyze oxychlorine thermal decomposition e.g., $[52,54,58]$. Iron-bearing phases (e.g., hematite, ferrihydrite) are known catalysts on perchlorate thermal decomposition, e.g., $[49,55,59]$. The Fe cation $\left(\mathrm{Fe}^{2+}\right.$ or $\left.\mathrm{Fe}^{3+}\right)$ in the mineral interacts with the unshared electron pair in the perchlorate or chlorate, thus weakening the $\mathrm{Cl}-\mathrm{O}$ bond and decreasing the thermal decomposition temperature $[49,60]$. Samples analyzed by both the Chemistry and Mineralogy (CheMin) X-ray diffraction (XRD) instrument and SAM contained a variety of iron-bearing phases (e.g., magnetite, hematite, 
jarosite, amorphous iron oxides) that could potentially catalyze the thermal decomposition of oxychlorines e.g., [61-64].

Mixtures of iron-bearing phases and perchlorates were analyzed on a laboratory SAMEGA analog instrument in order to determine whether iron-bearing phases detected in Gale crater would catalyze the thermal decomposition of oxychlorines. Aqueous solutions of $\mathrm{Ca}$ and $\mathrm{Mg}$ perchlorate salts were added to powdered iron-bearing phases including hematite, magnetite, ilmenite, pyrrohotite, fayalite/magnetite and palagonite using Marslike ratios [52]. These mixtures were desiccated and then analyzed on a SAM-EGA analog instrument [52]. Evolved gas data from the pure perchlorates were compared to data from the perchlorate/iron-bearing phase mixtures to assess the effect of iron-bearing phases on perchlorate thermal decomposition.

Select iron-bearing phases decreased the perchlorate $\mathrm{O}_{2}$ release peak temperature by 16-152 ${ }^{\circ} \mathrm{C}$, and this temperature depression was dependent on the type of iron-bearing phase in the mixture [52]. Ferrihydrite and palagonite (plagioclase feldspar, magnetite, minor pyroxene and hematite, basaltic glass, allophane, and nanophase ferric oxide) [65], both of which contain amorphous iron-oxides, decreased the $\mathrm{O}_{2}$ release temperature the most and produced $\mathrm{O}_{2}$ release peaks at similar temperatures as the Rocknest and John Klein samples analyzed by SAM [52]. This finding suggested that iron-rich amorphous materials in Rocknest and John Klein, which may contain nanophase iron oxides, interacted with perchlorates and caused $\mathrm{O}_{2}$ release peak temperatures between $\sim 300$ and $400{ }^{\circ} \mathrm{C}$ [52]. It is also possible that the perchlorates underwent cation exchange with iron-bearing phases when added by solution, thus producing Fe perchlorate, which has a low thermal decomposition temperature. Additionally, perchlorate mixtures with magnetite, hematite, fayalite-magnetite, ilmenite, and pyrrhotite produced $\mathrm{O}_{2}$ releases similar to the $\mathrm{O}_{2}$ release observed in Confidence Hills [52]. Although SAM-EGA analog studies of perchlorate/ironbearing phase mixtures explained some $\mathrm{O}_{2}$ releases in Gale crater samples, the lower temperature $\mathrm{O}_{2}$ releases observed in John Klein (peak 1), Cumberland, and Windjana remained unexplained. Additionally, mixtures of iron-bearing phases and perchlorates did not reproduce any of the $\mathrm{HCl}$ releases observed in Gale crater samples [58].

Adsorbed $\mathrm{ClO}_{4}{ }^{-}$onto ferrihydrite and akageneite particle surfaces was proposed as an explanation for the low-temperature $\mathrm{O}_{2}$ releases detected in several SAM samples, including Cumberland [66]. Synthesized ferrihydrite and akageneite were mixed with $\mathrm{HCl}$ or $\mathrm{NaOH}$ solutions in order to reach $\mathrm{pH}$ values ranging from 2 to 7.3 , and these solutions were then mixed with a Na perchlorate solution [66]. The iron-phase/Na perchlorate solutions were equilibrated and then washed using a centrifuge so that perchlorate and chloride salts were removed, leaving only adsorbed $\mathrm{ClO}_{4}{ }^{-}$and $\mathrm{Cl}^{-}$. These mixtures were dried and then analyzed on a SAM-analog instrument. Ferrihydrite samples with adsorbed $\mathrm{ClO}_{4}^{-}(\mathrm{pH} 2-\mathrm{pH} 4.5)$ evolved $\mathrm{O}_{2}$ at lower temperatures than the pure Na perchlorate salt, and these $\mathrm{O}_{2}$ releases were similar to that of the Cumberland sample analyzed by the SAM instrument [66]. Additionally, these mixtures evolved high-temperature $\mathrm{HCl}$ $\left(>600{ }^{\circ} \mathrm{C}\right)$ releases, which were tentatively attributed to adsorbed $\mathrm{Cl}^{-}$on ferrihydrite particle surfaces. The akageneite samples with adsorbed $\mathrm{ClO}_{4}{ }^{-}$evolved a negligible amount of $\mathrm{O}_{2}$ but did evolve mid-temperature $\left(300-600{ }^{\circ} \mathrm{C}\right) \mathrm{HCl}$ releases, which were attributed to $\mathrm{Cl}^{-}$from collapsing akageneite tunnels during heating [66]. The results from these experiments suggested that the $\mathrm{O}_{2}$ evolution in the Cumberland sample could be caused by $\mathrm{ClO}_{4}{ }^{-}$adsorbed onto ferrihydrite surfaces. Additionally, the high-temperature $\mathrm{HCl}$ release observed in Cumberland could be caused by adsorbed $\mathrm{Cl}^{-}$on ferrihydrite.

Pure chlorates and chlorate/iron-bearing-phase mixtures were evaluated to explain the $\mathrm{O}_{2}$ and $\mathrm{HCl}$ evolutions in Gale crater samples, which were unexplained by the perchlorate/iron-bearing-phase mixtures. $\mathrm{Mg}$, $\mathrm{Na}$, and $\mathrm{K}$ chlorate were added as solutions to powdered hematite, magnetite, ferrihydrite, and palagonite [31]. Two chlorate/ironbearing-phase molar ratios ( 1:1 and $\sim 1: 4)$ were prepared in order to test the effect of increasing the iron-bearing-phase/chlorate ratio on the chlorate decomposition temperature [31]. These samples were desiccated and analyzed on a SAM-EGA analog instrument. 
Iron-bearing phases decreased the $\mathrm{O}_{2}$ release peak temperature of chlorates by up to $\sim 215^{\circ} \mathrm{C}$, and the temperature reduction depended on the type of iron-bearing-phase in the mixture and the iron-bearing-phase/chlorate ratio [31]. Mixtures of $\mathrm{K}$ chlorate with magnetite, hematite, palagonite, and ferrihydrite caused an $\mathrm{O}_{2}$ release peak reduction of $112-142{ }^{\circ} \mathrm{C}$ [31]. Mixtures of $\mathrm{Na}$ and $\mathrm{Mg}$ chlorate with the same iron-bearing phases caused an $\mathrm{O}_{2}$ release peak reduction of $72-214$ and $35-149^{\circ} \mathrm{C}$, respectively [31] (Figure 5). The only mixtures that produced $\mathrm{HCl}$ releases were those with $\mathrm{Mg}$ chlorate. The $\mathrm{HCl}$ release peaks from $\mathrm{Mg}$ chlorate decreased by $33-170{ }^{\circ} \mathrm{C}$ when mixed with iron-bearing phases [31]. Similar to Sutter et al. [52], ferrihydrite and palagonite caused the greatest depression in $\mathrm{O}_{2}$ release peak temperature out of all the chlorate/iron-bearing phase mixtures, and this was attributed to their high surface areas [67]. Additionally, the chlorate mixtures with the higher iron-bearing phase/chlorate ratios caused a greater reduction in $\mathrm{O}_{2}$ release peak temperature than mixtures with lower iron-bearing phase/chlorate ratios. This was attributed to the differences in total iron available to catalyze the chlorate decomposition [31].

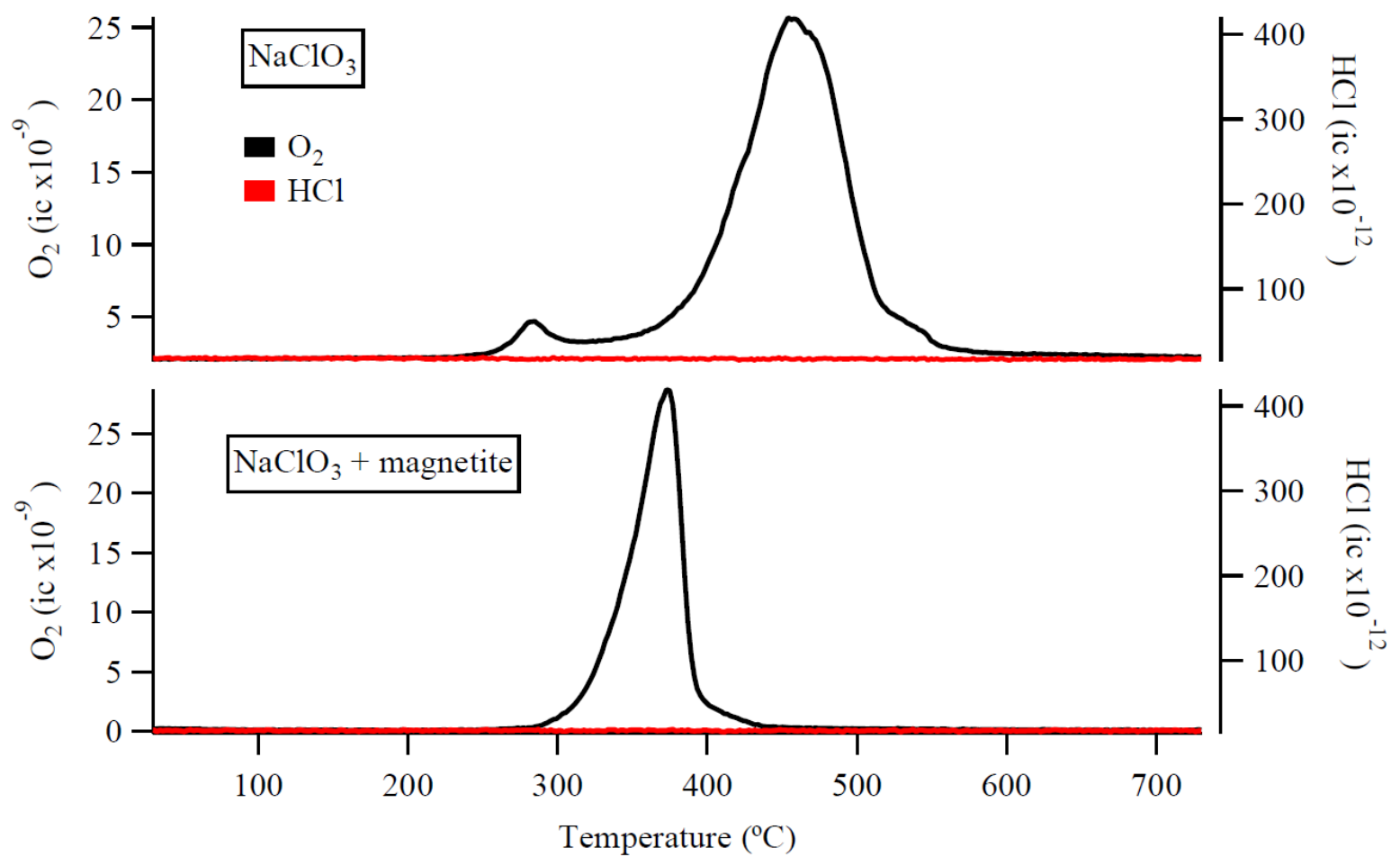

Figure 5. Example showing the effect of iron-bearing phases on chlorate $\mathrm{O}_{2}$ release temperature. This example shows evolved $\mathrm{O}_{2}$ and $\mathrm{HCl}$ from $24 \mu \mathrm{mol} \mathrm{NaClO}_{3}$ by itself and mixed with $100 \mu \mathrm{mol}$ magnetite. Data from [31]. ic = ion current (Amperes).

Iron-bearing phases also consume oxygen during oxychlorine decomposition [52]. Mixtures of chlorates with iron-bearing phases evolved less oxygen than the same amount of chlorate analyzed without iron-bearing phases [31]. The amount of oxygen consumption was up to $75 \%$, and was dependent on the type of iron-bearing phase, the iron-bearing phase/chlorate ratio, and the type of chlorate [31]. Mixtures with a higher iron content typically experienced more oxygen consumption during thermal analysis. Magnetite consumed the most oxygen in mixtures with $\mathrm{Na}$ and $\mathrm{K}$ chlorate, and the second-most amount of oxygen in the $\mathrm{Mg}$ chlorate mixtures [31]. Oxygen consumption in the magnetite mixtures was attributed to oxidation of $\mathrm{Fe}^{2+}$ to $\mathrm{Fe}^{3+}$ in the presence of $\mathrm{O}_{2}$ from chlorate decomposition. Oxygen consumption in the other mineral mixtures was attributed to the presence of oxygen deficient sites on the mineral surfaces in oxides [68,69], which could complex with oxygen evolved from chlorate decomposition. This finding demonstrated 
that the amount of oxychlorines calculated from SAM oxygen peak integrations could be an underestimate.

Most oxygen releases from Gale crater that peaked at too low a temperature to be explained by the presence of perchlorates (e.g., Windjana, Cumberland) could be explained by chlorate/iron-bearing phase mixtures or ferrihydrite with adsorbed $\mathrm{ClO}_{4}{ }^{-}[31,66]$. Although laboratory analog work provided an explanation for most of the oxygen releases detected by SAM in Gale crater samples, they did not explain most of the $\mathrm{HCl}$ releases. The only chlorate or perchlorate/iron-bearing phase mixtures that evolved $\mathrm{HCl}$ with peaks within the range of SAM were $\mathrm{Mg}$ and Fe oxychlorines [31,52,53]. However, SAM samples with high-temperature $\mathrm{HCl}$ release peaks $>600{ }^{\circ} \mathrm{C}$ (e.g., Rocknest, John Klein) could not be explained by $\mathrm{Mg}$ or $\mathrm{Fe}$ oxychlorines because they evolve $\mathrm{HCl}$ at lower temperatures.

\subsubsection{Water-Evolving Phases}

$\mathrm{HCl}$ releases from Gale crater samples either co-evolved with $\mathrm{O}_{2}$ below $600{ }^{\circ} \mathrm{C}$ or occurred at higher temperatures $\left(>600^{\circ} \mathrm{C}\right.$ ) (Figure 4). Some samples with high-temperature $\left(>600{ }^{\circ} \mathrm{C}\right) \mathrm{HCl}$ releases evolved $\mathrm{O}_{2}$, and some did not evolve $\mathrm{O}_{2}$ (Figure 6). These hightemperature $\mathrm{HCl}$ releases were not explained by previous studies involving perchlorates, chlorates, or oxychlorine/iron-bearing phase mixtures. Adsorbed $\mathrm{Cl}^{-}$on ferrihydrite surfaces could contribute to high-temperature $\mathrm{HCl}$ releases [66]. Chlorides (original or from oxychlorine decomposition) can react with water and evolve $\mathrm{HCl}[70,71]$, and this was proposed as a mechanism for the high-temperature $\mathrm{HCl}$ evolutions observed in the SAM data e.g., [26].

Mixtures of perchlorates with water-evolving phases were analyzed in a laboratory SAM-EGA analog instrument in order to determine whether high-temperature $\mathrm{HCl}$ releases were caused by the interaction between melting chlorides and water [29]. Chloride/waterevolving phase mixtures were also tested to understand whether $\mathrm{HCl}$ could be evolved from chlorides without the presence of perchlorates. Nontronite, saponite, and basaltic glass were used as Gale crater-analog water-evolving phases [26,61,62,64,72-74]. Mg perchlorate, $\mathrm{Na}$ perchlorate, $\mathrm{Mg}$ chloride, and $\mathrm{Na}$ chloride were individually added as solutions to powdered water-evolving phases (i.e., saponite, nontronite, basaltic glass), desiccated, and then analyzed on a SAM-EGA analog instrument [29]. The evolved gases (e.g., $\mathrm{H}_{2} \mathrm{O}, \mathrm{O}_{2}, \mathrm{HCl}$ ) from these laboratory mixtures were compared to data from the SAM instrument on Mars.

All mixtures of $\mathrm{Mg}$ perchlorate with water-evolving phases released $\mathrm{HCl}$ within the temperature range of SAM [29]. Mg perchlorate by itself and mixed with water-producing phases evolved mid-temperature $\mathrm{HCl}$ with peaks between 485 and $545{ }^{\circ} \mathrm{C}$, due to the decomposition of $\mathrm{Mg}$ perchlorate to $\mathrm{MgO}$ (reactions 1 and 2). Mixtures of $\mathrm{Mg}$ perchlorate with nontronite or basaltic glass evolved mid-temperature $\mathrm{HCl}$ releases as expected, but the $\mathrm{Mg}$ perchlorate/saponite mixture produced an additional $\mathrm{HCl}$ release with a peak at $824{ }^{\circ} \mathrm{C}$. The $\mathrm{HCl}$ release peak at $824{ }^{\circ} \mathrm{C}$ in the $\mathrm{Mg}$ perchlorate/saponite mixture was attributed to melting chlorides reacting with water from saponite dehydroxylation [29]. The chlorides formed on particle surfaces through a reaction between the evolved $\mathrm{HCl}$ and interlayer cations such as $\mathrm{Na}^{+}$and $\mathrm{Ca}^{2+}$ (e.g., reactions 9 and 10). The formation of chlorides during thermal analysis of the saponite $/ \mathrm{Mg}$ perchlorate mixture was confirmed using ion chromatography. 


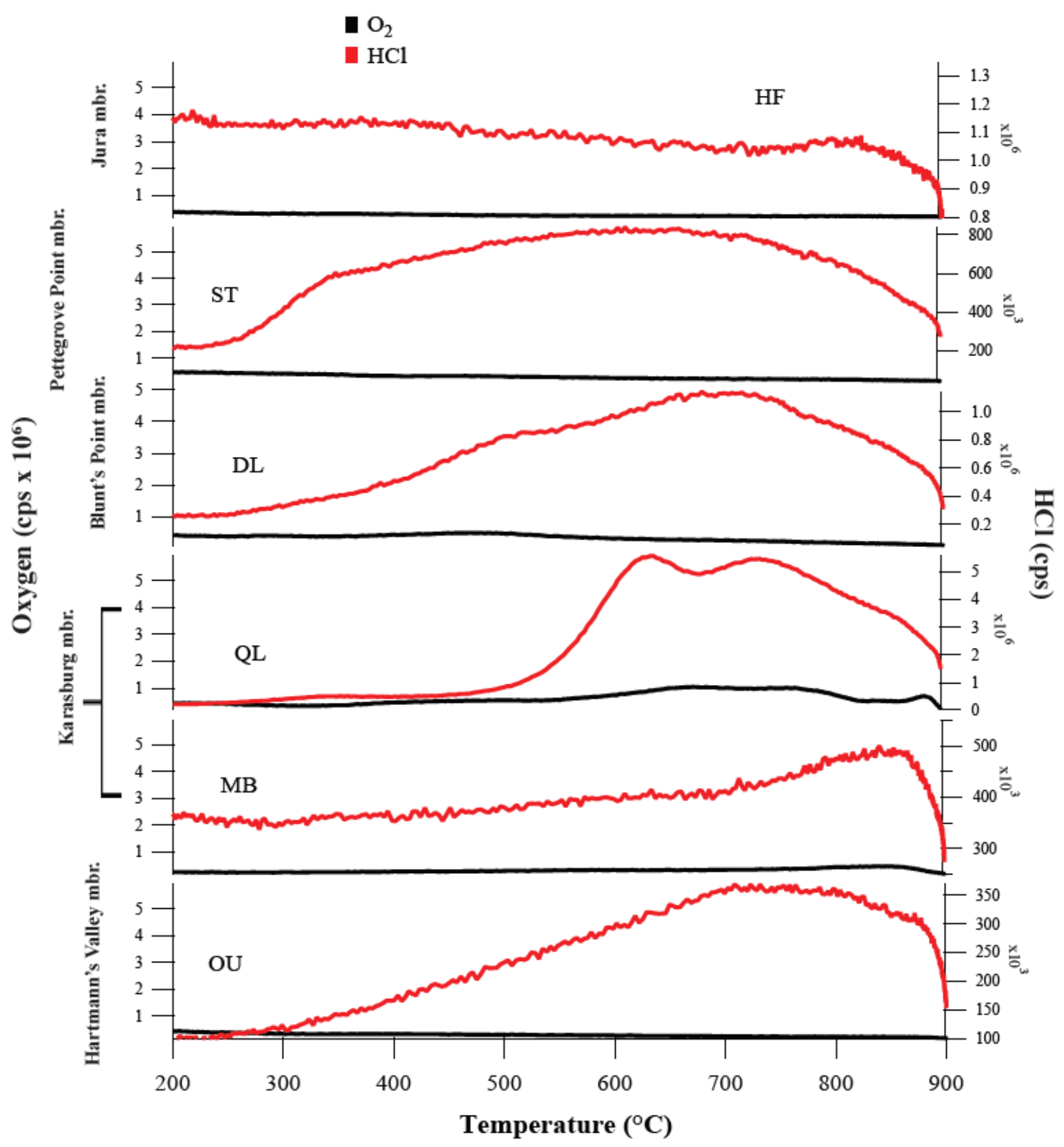

Figure 6. Evolved $\mathrm{O}_{2}(\mathrm{~m} / \mathrm{z}$ 32) and $\mathrm{HCl}(\mathrm{m} / \mathrm{z}$ 36) profiles measured by the SAM QMS in counts/sec (cps) during pyrolysis of Murray formation samples in Gale crater that did not evolve $\mathrm{O}_{2}$. Abbreviations: $\mathrm{OU}=\mathrm{Oudam}, \mathrm{MB}=\mathrm{Marimba}, \mathrm{QL}=\mathrm{Quela}$, $\mathrm{DL}=$ Duluth, $\mathrm{ST}=$ Stoer, and HF = Highfield. Samples are labeled by members (mbr.) within the Murray formation. Samples are ordered stratigraphically, with the stratigraphically lowest sample on the bottom.

$$
\begin{aligned}
\text { Exchange- } \mathrm{Ca}^{2+}+2 \mathrm{HCl} & \rightarrow \mathrm{CaCl}_{2}+2 \text { Exchange- }^{+} \\
\mathrm{CaCl}_{2}+\mathrm{H}_{2} \mathrm{O} & \rightarrow \mathrm{CaO}+2 \mathrm{HCl}
\end{aligned}
$$

where "exchange" refers to exchangeable cations in the interlayer of saponite.

Na perchlorate by itself did not evolve $\mathrm{HCl}$ within the temperature range of SAM. However, the mixtures of Na perchlorate with the water-evolving phases did evolve $\mathrm{HCl}$ (e.g., Figure 7) [29]. The $\mathrm{HCl}$ releases from these mixtures occurred at the same temperature as the water release from phyllosilicate dehydroxylation or from water inclusions. $\mathrm{HCl}$ 
releases in the Na perchlorate mixtures resulted from the reaction between water and the $\mathrm{NaCl}$ from perchlorate decomposition (reactions 11 and 12).

$$
\begin{gathered}
2 \mathrm{NaClO}_{4} \rightarrow 2 \mathrm{NaCl}+4 \mathrm{O}_{2} \\
2 \mathrm{NaCl}+\mathrm{H}_{2} \mathrm{O} \rightarrow 2 \mathrm{HCl}+\mathrm{Na}_{2} \mathrm{O}
\end{gathered}
$$

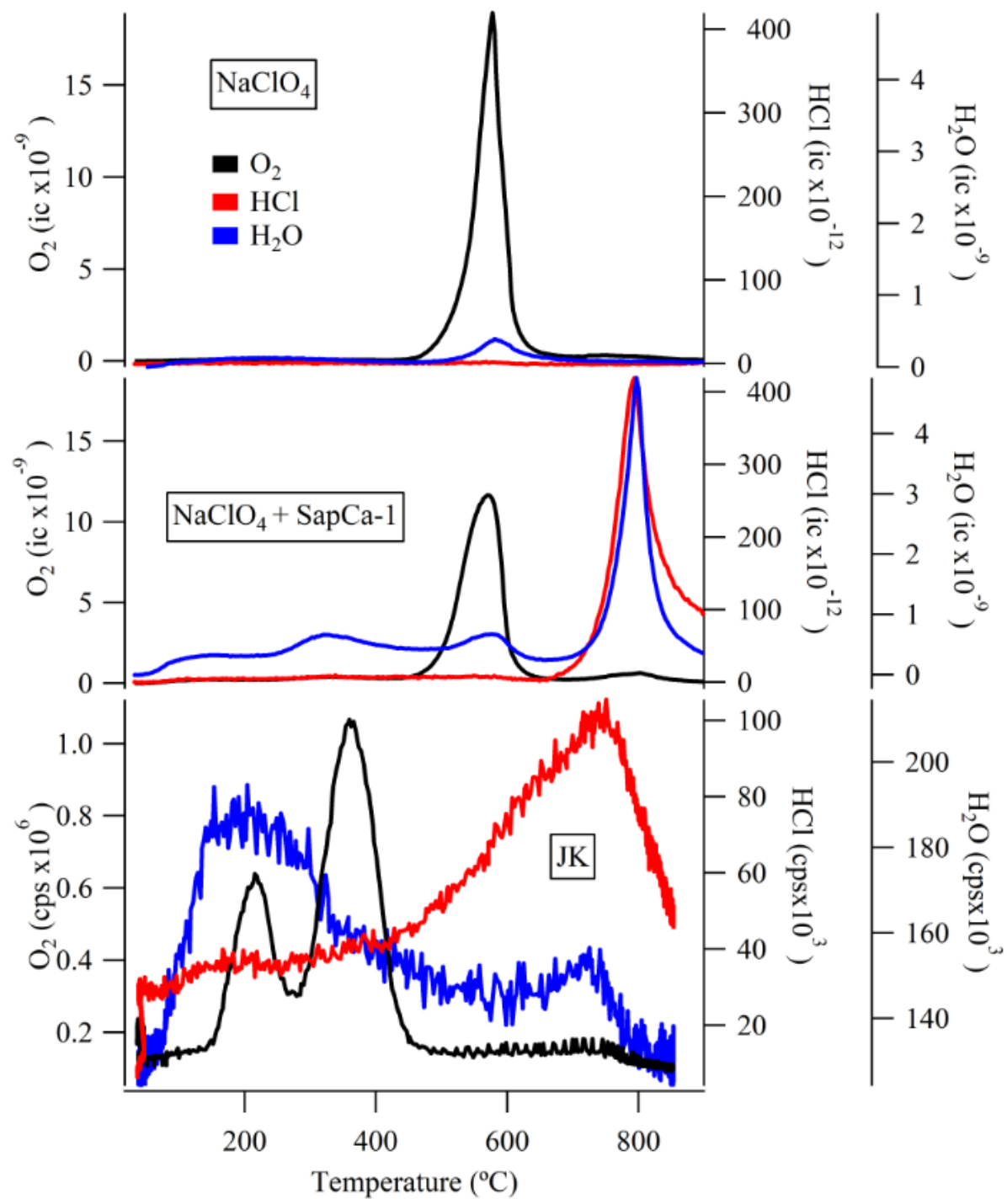

Figure 7. Example showing the effect of water-evolving phases on $\mathrm{HCl}$ evolutions from mono-cation perchlorates. This example shows evolved $\mathrm{O}_{2}, \mathrm{HCl}$, and $\mathrm{H}_{2} \mathrm{O}$ from $24 \mu \mathrm{mol} \mathrm{NaClO} \mathrm{N}_{4}$ by itself and mixed with 20 mg SapCa-1 saponite, compared to John Klein (JK) analyzed by SAM. Data from [29]. ic $=$ ion current (Amperes).

$\mathrm{Mg}$ chloride by itself and mixed with water-evolving phases evolved $\mathrm{HCl}$ with peaks between $\sim 400$ and $600{ }^{\circ} \mathrm{C}$ (reaction 13).

$$
x \mathrm{MgCl}_{2} \cdot x \mathrm{H}_{2} \mathrm{O} \rightarrow x \mathrm{MgO}+2 x \mathrm{HCl}
$$

$\mathrm{Na}$ chloride by itself did not evolve $\mathrm{HCl}$ as expected but it did evolve $\mathrm{HCl}$ when mixed with the water-producing phases. Mixtures of $\mathrm{NaCl}$ with saponite and the basaltic glass both produced $\mathrm{HCl}$ releases with peaks at $\sim 800{ }^{\circ} \mathrm{C}$ that co-occurred with water releases (e.g., Figure 8). The nontronite/ $\mathrm{NaCl}$ mixture evolved two $\mathrm{HCl}$ release peaks, one at 
the same temperature as nontronite dehydroxylation and another at the melting point of $\mathrm{NaCl}$ [29]. $\mathrm{HCl}$ releases in the $\mathrm{NaCl}$ mixtures were attributed to solid or melting chlorides reacting with water from inclusions or from phyllosilicate dehydroxylation [29].

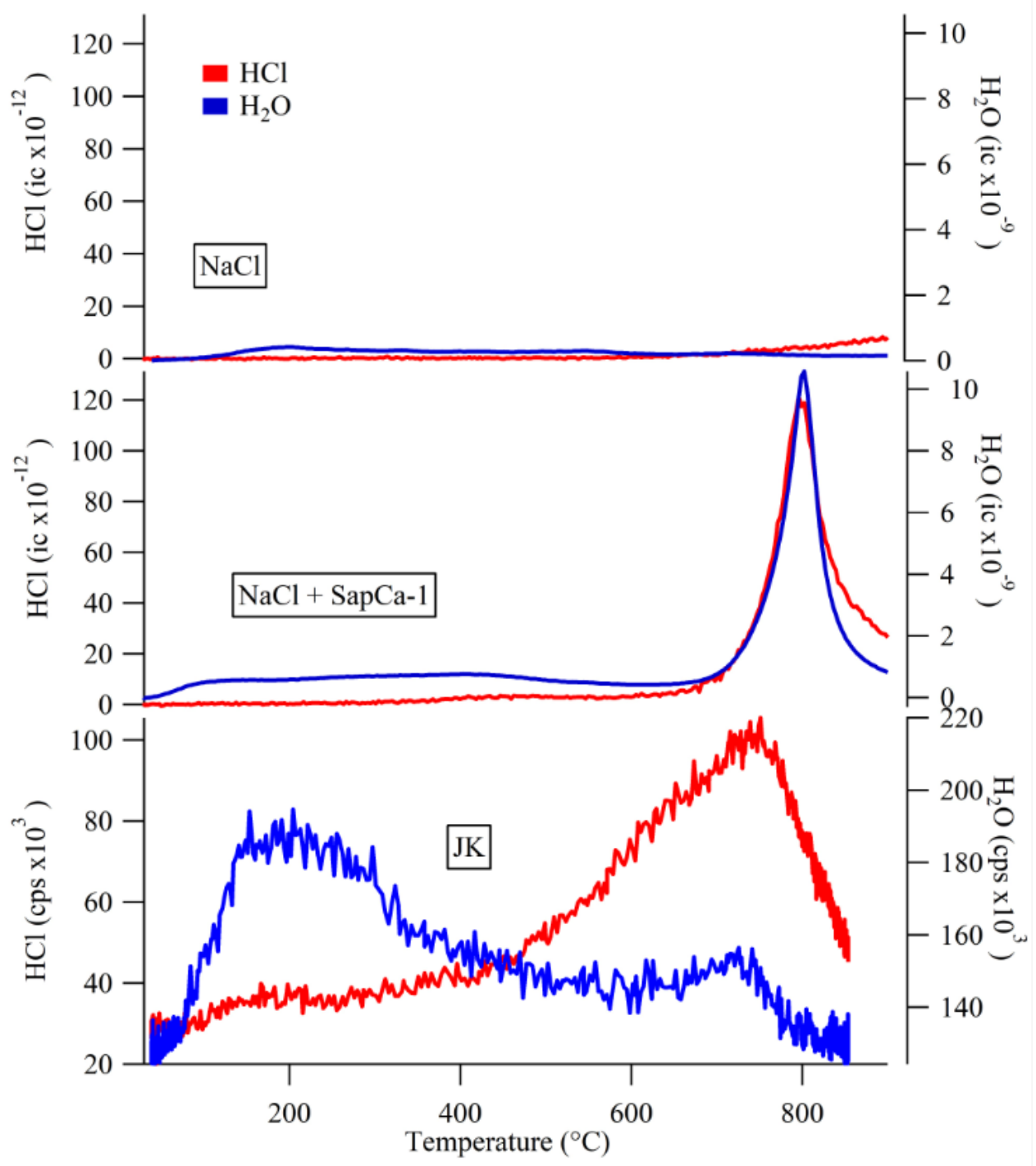

Figure 8. Example showing the effect of water-evolving phases on $\mathrm{HCl}$ evolutions from mono-cation chlorides. This example shows evolved $\mathrm{O}_{2}, \mathrm{HCl}$, and $\mathrm{H}_{2} \mathrm{O}$ from $24 \mu \mathrm{mol} \mathrm{NaCl}$ by itself and mixed with $20 \mathrm{mg}$ SapCa- 1 saponite, compared to the John Klein (JK) sample analyzed by SAM. Data from [29]. ic = ion current (Amperes).

The results from these laboratory analog experiments demonstrated that chlorides (original or from oxychlorine decomposition) react with water in the oven to produce high-temperature $\left(>600^{\circ} \mathrm{C}\right) \mathrm{HCl}$ releases [29]. Many of the $\mathrm{HCl}$ releases from Gale crater samples evolved high-temperature $\mathrm{HCl}$ releases similar to those observed in laboratory mixtures of perchlorates and chlorides with water-producing phases (e.g., Figures 7 and 8).

\subsubsection{Carbonates and Sulfates}

Carbonates can also interact with oxychlorines during thermal analysis and may impact evolved gas patterns and abundances from samples analyzed by the SAM instrument in Gale crater. A study utilizing laboratory evolved gas analysis and heated XRD [48] demonstrated the interaction between hydrated $\mathrm{Mg}$ perchlorate and calcite during thermal analysis. Results showed that when calcite was mixed with $\mathrm{Mg}$ perchlorate, there was a low-temperature $\mathrm{CO}_{2}$ release (onset of $\sim 385^{\circ} \mathrm{C}$ ) in addition to the higher temperature $\mathrm{CO}_{2}$ 
release caused by calcite thermal decomposition (onset of $\sim 680^{\circ} \mathrm{C}$; reaction 14) [48]. The lower temperature $\mathrm{CO}_{2}$ release was attributed to an inorganic reaction between calcite and evolved $\mathrm{HCl}$ and water from the hydrated $\mathrm{Mg}$ perchlorate (reaction 15). The magnitude of the low-temperature $\mathrm{CO}_{2}$ release increased with increasing $\mathrm{Mg}$ perchlorate to calcite ratio, and thus $\mathrm{HCl}$ was consumed in this process. It is possible that low-temperature $\mathrm{CO}_{2}$ releases observed in SAM data may be the result of $\mathrm{HCl}$ from oxychlorine or chloride thermal decomposition reacting with carbonates.

$$
\mathrm{Mg}\left(\mathrm{ClO}_{4}\right)_{2} \cdot x \mathrm{H}_{2} \mathrm{O} \rightarrow \mathrm{MgO}+(3.5+0.5 x) \mathrm{O}_{2}+\mathrm{HCl}+(1-x) \mathrm{Cl}_{2}
$$

where $x<1$.

$$
\mathrm{CaCO}_{3}+2 \mathrm{HCl} \rightarrow \mathrm{CaCl}_{2}+\mathrm{CO}_{2}+\mathrm{H}_{2} \mathrm{O}
$$

Sulfates can react with chlorides (original or from oxychlorine thermal decomposition) in the sample to produce $\mathrm{HCl}$ via "Hargreaves reaction" [75], and this may explain several of the $\mathrm{HCl}$ releases above $\sim 500{ }^{\circ} \mathrm{C}$ in the SAM data. Using $\mathrm{NaCl}$ as an example, water reacts with the solid or liquid chloride to produce $\mathrm{HCl}$ and $\mathrm{Na}_{2} \mathrm{O}$ (reaction 16) [70,76]. $\mathrm{Na}_{2} \mathrm{O}$ can then react with $\mathrm{SO}_{2}$ gas from sulfate decomposition and produce $\mathrm{Na}$ sulfate (reaction 17) [70,76]. When $\mathrm{Na}_{2} \mathrm{O}$ is consumed, reaction 16 shifts to the right and $\mathrm{HCl}$ production increases. SAM laboratory analog studies have demonstrated that mixtures of kieserite $\left(\mathrm{MgSO}_{4} \cdot \mathrm{H}_{2} \mathrm{O}\right)$ and $\mathrm{NaCl}$ produced high-temperature $\mathrm{HCl}$ releases similar to those observed in SAM data [37].

$$
\begin{gathered}
\mathrm{H}_{2} \mathrm{O}_{(\mathrm{g})}+2 \mathrm{NaCl}_{(\mathrm{s}, \mathrm{l})} \rightarrow 2 \mathrm{HCl}_{(\mathrm{g})}+\mathrm{Na}_{2} \mathrm{O} \\
\mathrm{SO}_{2}+1 / 2 \mathrm{O}_{2}+\mathrm{Na}_{2} \mathrm{O} \rightarrow \mathrm{Na}_{2} \mathrm{SO}_{4(\mathrm{~s}, \mathrm{l})}
\end{gathered}
$$

\subsubsection{Evolved $\mathrm{O}_{2}$ and $\mathrm{HCl}$ in Mars-Analog Materials}

The aforementioned effects of martian analog phases (e.g., sulfates, water-producing phases, iron-bearing phases) were observed in laboratory evolved gas analyses of martian simulants, which are mineral/rock mixtures designed to mimic natural martian soil for the purpose of research and equipment testing. The Johnson Space Center Rocknest (JSC-RN) simulant contained Na perchlorate in addition to Ca sulfate, water-evolving phases, and iron-bearing phases (e.g., ferrihydrite) [77]. JSC-RN evolved oxygen with a peak at $312{ }^{\circ} \mathrm{C}$, similar but slightly lower than what was observed in the Rocknest sample analyzed by SAM on Mars [27]. Na perchlorate by itself evolved oxygen with a peak at $578{ }^{\circ} \mathrm{C}$ (Table 2). The $>200{ }^{\circ} \mathrm{C}$ decrease in $\mathrm{O}_{2}$ release peak temperature from $\mathrm{Na}$ perchlorate thermal decomposition demonstrates how iron-bearing phases catalyze the thermal decomposition of perchlorates in more complex martian analog mixtures. The JSC-RN mixture prepared in the laboratory also evolved two $\mathrm{HCl}$ releases, both coinciding with $\mathrm{SO}_{2}$ releases [77].

\subsection{Implications for Gale Crater Samples}

SAM-EGA laboratory analog studies demonstrated that the $\mathrm{O}_{2}$ and $\mathrm{HCl}$ evolutions observed in Gale crater samples may be caused by the presence of perchlorates or chlorates, and that the $\mathrm{O}_{2}$ and $\mathrm{HCl}$ release temperatures are strongly affected by other phases present in the sample (e.g., water-evolving phases and iron-bearing phases). Analog work has demonstrated that high-temperature $\mathrm{HCl}$ evolutions may also be caused by chlorides (original or from oxychlorine decomposition) reacting with evolved water from phases in the sample. Table 1 shows the oxychlorines or chlorides that may be present in Gale crater samples based on their $\mathrm{O}_{2}$ and $\mathrm{HCl}$ release patterns and peak temperatures. Additionally, these SAM-EGA analog studies showed that the amount of oxychlorines reported based on $\mathrm{SAM} \mathrm{O}_{2}$ peak integrations could be an underestimate due to oxygen consumption by iron-bearing phases such as magnetite or ferrihydrite. 
The presence of chlorate, in addition to perchlorate, in Gale crater surface materials has implications for understanding the chlorine cycle on Mars. Various mechanisms of one-way oxychlorine formation have been proposed. Some studies suggest that chlorate, like perchlorate, is an end-product of oxychlorine oxidation $[4,78]$. Chlorate can also be produced in the laboratory by exposing aqueous hypochlorite or chlorite to UV radiation [78]. Quinn et al. [79] suggested that oxychlorine formation is bi-directional (i.e., chlorate forms from perchlorate and vice versa). Perchlorate could degrade to chlorate by being exposed to ionizing radiation over time [79]. The presence of chlorate on Mars suggests that chlorate formation is bi-directional or that not all chlorine has been completely oxidized to perchlorate. Knowledge of the locations and abundances of chlorates and perchlorates on Mars could help constrain the rates and mechanisms of oxychlorine production.

Knowledge of the abundance and types of oxychlorines present on Mars also has implications for understanding atmospheric $\mathrm{O}_{2}$ and $\mathrm{HCl}$. Trainer et al. [80] suggested that surface perchlorates may contribute to the seasonal $\mathrm{O}_{2}$ variation observed in Gale crater, although it is currently unknown whether this contribution is significant. Although $\mathrm{O}_{2}$ is a radiolysis product of surface perchlorates salts [79], the $\mathrm{O}_{2}$ production rate from perchlorate radiolysis is too slow to account for the measured seasonal $\mathrm{O}_{2}$ variation in Gale crater [80]. Additionally, atmospheric $\mathrm{HCl}$ was detected by spectrometers on board the Trace Gas Orbiter (TGO) and was present at higher concentrations globally after dust storms, particularly the strong dust storm during Mars Year 34 [81]. $\mathrm{HCl}$ detections by TGO have been attributed to chlorine-bearing species (i.e., chlorides, oxychlorines) in atmospheric dust reacting with water [81].

Knowledge of the distribution of perchlorate, chlorate, and chloride species on the martian surface can provide insights into past aqueous conditions. The solubility of oxychlorines and chlorides is dependent on the anion $\left(\mathrm{ClO}_{4}{ }^{-}, \mathrm{ClO}_{3}{ }^{-}, \mathrm{Cl}^{-}\right)$and the cation (e.g., $\mathrm{Mg}, \mathrm{Ca}, \mathrm{Na}, \mathrm{K}, \mathrm{Fe}$ ). For example, at $25^{\circ} \mathrm{C}$, Na perchlorate has a solubility of $205 \mathrm{~g} / 100 \mathrm{~g}$ water whereas $\mathrm{Mg}$ perchlorate has a solubility of $100 \mathrm{~g} / 100 \mathrm{~g}$ water [82]. Additionally, chlorides are generally less soluble than oxychlorines. For example, at $25{ }^{\circ} \mathrm{C} \mathrm{NaCl} \mathrm{has} \mathrm{a}$ solubility of $36 \mathrm{~g} / 100 \mathrm{~g}$ water and $\mathrm{MgCl}_{2}$ has a solubility of $56 \mathrm{~g} / 100 \mathrm{~g}$ water [82]. Oxychlorine and chloride salts in Gale crater may be stratified based on their solubilities, similar to salts in terrestrial environments including the Atacama Desert, Chile, and Death Valley, California [28,83-87]. Several samples in the upper Murray formation showed evidence for the presence of chlorides (and not oxychlorines) whereas samples in the Yellowknife Bay, Kimberley, and lower Murray formations did show evidence for the presence of oxychlorines (Figure 3). One explanation for this trend is that the more soluble species (i.e., oxychlorines) leached out of the upper Murray formation, leaving behind less soluble species (i.e., chlorides) (Figure 3) [28]. Alternatively, it is possible that oxychlorines were not deposited at the sampled locations in the upper Murray formation.

The presence of oxychlorines in Gale crater has implications for past and present microbial habitability. Microorganisms can use the perchlorate anion as a terminal electron acceptor under anoxic conditions in terrestrial groundwater e.g., [88]. Approximately 100 strains of oxychlorine-reducing microbes have been identified on Earth, most of these being Proteobacteria [89]. Most oxychlorine-reducing bacteria grow under neutral $\mathrm{pH}$ and low-salinity conditions. However, there are some halophilic, thermophilic, and hyperthermophilic perchlorate-reducing bacteria [89]. On Mars, oxychlorine salts could be used in microbial respiration, although high activity perchlorate or chlorate solutions are not favorable to most life.

Furthermore, the thermal decomposition of oxychlorines can result in the partial to complete oxidation by $\mathrm{O}_{2}$ (combustion) or by $\mathrm{Cl}$ (chlorination) of some organics in a sample [18]. Oxidants, including perchlorates, have been shown to decompose organic molecules in terrestrial organic matter and in terrestrial organic-containing soils e.g., [42,90-92]. However, the amount of oxidation that occurs, and products formed, will depend on the chemistry and packaging of organic materials and the oxychlorine phases in a sample. In some cases organic material survives oxidation during thermal analyses 
as demonstrated by SAM's detection of organic compounds in samples also containing perchlorates [93-95]. In particular, aromatic, aliphatic, and thiophenic products evolve at temperatures higher than oxychlorine $\mathrm{O}_{2}$ releases [94]. Nevertheless, laboratory SAManalog work has demonstrated that the chlorohydrocarbons detected in SAM samples (e.g., Rocknest, Cumberland) may be the result of indigenous organics reacting with oxychlorines [93,95], although it is also plausible that they could be natural products of the radiation of oxychlorines and indigenous organics [96].

Knowledge of the types and abundances of oxychlorine species is important for interpreting organic signals and their implications for habitability in Viking TV-GC-MS, MSL SAM, Phoenix TEGA, and ExoMars 2022 Mars Organic Molecule Analyzer (MOMA) data. Additionally, understanding the effects of oxychlorines on organics during sample heating will be important if future returned samples from Jezero crater, Mars are analyzed using thermal and evolved gas analysis or other organic analyses that involve heating. As mentioned previously, oxychlorines are widespread on the martian surface e.g., $[13,25,27,31,38,51]$ and are likely to be present in Jezero crater. Returned samples from Jezero crater should not be analyzed for organics using methods that involve heat (e.g., pyrolysis-gas chromatography-mass spectrometry (GC-MS)) without removing oxychlorines prior to analysis because the oxychlorines may oxidize some organics in the sample. Methods such as leaching can be used to rid soil samples of perchlorates prior to organic analyses [97]. Alternatively, martian surface materials that have an organic carbon to perchlorate ratio above 4.7-9.6 should be targeted for return-sample collection so that organics are detectable using pyrolysis GC-MS [92].

Constraining the types of oxychlorines present on Mars has implications for the presence of liquid brines and thus, present day aqueous processes (e.g., the formation of RSL's). Perchlorates and chlorates have low eutectic temperatures and relative stabilities as liquids. At a relative humidity of $<1 \%, \mathrm{Mg}$ chlorate has the lowest eutectic point (204 K) compared to $\mathrm{Ca}, \mathrm{K}$, and Na chlorate [14]. Mg perchlorate also has a relatively low eutectic point compared to other perchlorates ( 206 K) [15], although Ca perchlorate's eutectic point is slightly lower ( 196 K) [15]. The Mg oxychlorine detected in Big Sky and Cumberland was more likely to deliquesce than most other oxychlorines. However, experimental work demonstrated that measured environmental conditions in Gale crater were not favorable for the presence of $\mathrm{Mg}$ oxychlorine brines on the surface (Primm et al., 2018). Geochemical modeling by Martín-Torres et al. [98] demonstrated that oxychlorines, particularly Ca perchlorate, could exist as transient brines in Gale crater surface materials. The presence of liquid brines will also be investigated in Oxia Planum, the landing site of the ExoMars platform/rover. The Brine Observation Transition to Liquid Experiment (BOTTLE) experiment on the Habitability: Brine Irradiation and Temperature (HABIT) instrument on board the ExoMars platform contains cells with $\mathrm{CaCl}_{2}, \mathrm{Fe}_{2}\left(\mathrm{SO}_{4}\right)_{2}, \mathrm{Mg}\left(\mathrm{ClO}_{4}\right)_{2}$, and $\mathrm{NaClO}_{4}$ [99]. The cells will be exposed to the martian atmosphere and electrical conductivity will be used to monitor the deliquescence process. These experiments will demonstrate which, if any, salts deliquesce under martian surface conditions.

Placing constraints on the types of oxychlorines present in Gale crater samples also has implications for understanding past geochemical conditions and diagenesis. For example, Cumberland and John Klein were only separated by a lateral and vertical distance of $2.75 \mathrm{~m}$ and $10 \mathrm{~cm}$, respectively [54]. Mg perchlorate or chlorate was detected in Cumberland but not in John Klein, indicating that they were exposed to different diagenetic fluids (Figure 9). The area surrounding the John Klein and Cumberland drill holes exhibited features indicative of early diagenesis, including raised ridges and sulfate-rich veins (Figure 9) $[61,100]$. The difference in oxychlorine composition between John Klein and Cumberland may have been caused by non-pervasive fluid pathways, where Cumberland was exposed to Mg-rich diagenetic fluids and John Klein was not. Diagenesis by $\mathrm{Mg}$ rich fluids was further supported by the possible detection of $\mathrm{Mg}-\mathrm{OH}$ pillaring in the Cumberland smectite interlayer [61]. 


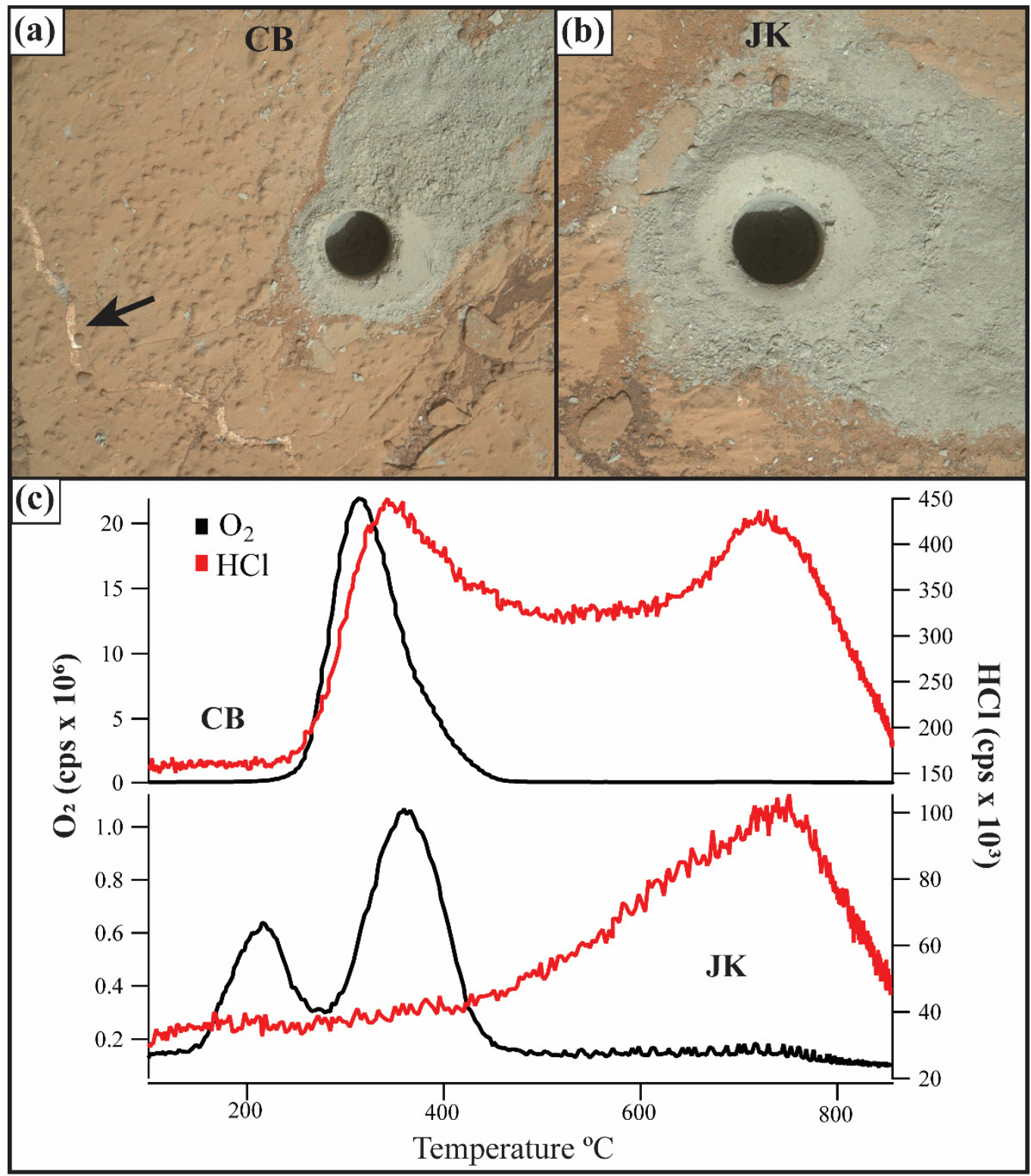

Figure 9. Mars Han Lens Imager (MAHLI) images of the (a) Cumberland (CB) and (b) John Klein (JK) drill holes, which were only separated by a lateral and vertical distance of $2.75 \mathrm{~m}$ and $10 \mathrm{~cm}$, respectively. Arrow points to a raised ridge, indicative of diagenesis, near the Cumberland drill hole. Bottom pane (c) shows evolved $\mathrm{O}_{2}$ and $\mathrm{HCl}$ from $\mathrm{JK}$ and $\mathrm{CB}$ as detected by the SAM instrument.

Understanding oxychlorines on Mars is also important for future human exploration because they could serve as valuable resources and harmful substances e.g., [101-103]. Oxychlorines could serve as a valuable resource by providing $\mathrm{H}_{2} \mathrm{O}$ and breathable $\mathrm{O}_{2}$. Approximately $60 \mathrm{~kg}$ of martian regolith could provide a daily supply of oxygen for one astronaut, assuming previously measured $\mathrm{ClO}_{4}{ }^{-}$abundances for regolith and complete decomposition through heating or microbial reduction [101]. Additionally, if surface conditions (i.e., temperature and relative humidity) are conducive to the formation of oxychlorine brines, they could be utilized as a source of $\mathrm{H}_{2} \mathrm{O}$ for drinking or for irrigating greenhouses after processing. $\mathrm{H}_{2} \mathrm{O}$ can also be split into $\mathrm{H}_{2}$ or $\mathrm{O}_{2}$ and used as propellent or for breathable $\mathrm{O}_{2}$. The BOTTLE experiment on the ExoMars platform will heat and then re-expose perchlorate salts to the martian atmosphere to demonstrate their in situ resource utilization (ISRU) potential for obtaining water [99]. Despite the ISRU value of oxychlorines, they could potentially pose a health hazard to future astronauts. The main 
routes of oxychlorine ingestion by humans on Mars would be through drinking water from the soil or from ice, eating plants grown in the soil, or inhaling dust [101,102]. Perchlorate inhibits iodide uptake by the thyroid gland, decreasing thyroidal hormone production. However, the effects of long-term and high-dose consumption of perchlorate in drinking water is unknown and is a concern for future human exploration of Mars.

The health effects of other Cl-oxyanions are not as well understood but could pose a threat to future astronauts on Mars. $\mathrm{ClO}_{2}{ }^{-}$and $\mathrm{ClO}$, both products of perchlorate irradiation, are more reactive than perchlorates and can cause additional health issues such as respiratory illness, headaches, loss of consciousness, and vomiting [101]. The more reactive $\mathrm{Cl}^{-}$oxyanions may also corrode astronaut suits and other flight materials.

\section{Conclusions}

Laboratory SAM-EGA analog research has provided further evidence for the existence of oxychlorines in Gale crater and has provided constraints on their speciation. Laboratory analog work demonstrated that perchlorates and chlorates evolve $\mathrm{O}_{2}$ upon thermal decomposition, and the $\mathrm{O}_{2}$ release temperature is dependent on the anion $\left(\mathrm{ClO}_{4}{ }^{-}\right.$or $\left.\mathrm{ClO}_{3}{ }^{-}\right)$, the cation (e.g., $\mathrm{Na}, \mathrm{K}, \mathrm{Ca}, \mathrm{Mg}$ ), and other phases present in the sample. Generally, perchlorates thermally decompose at a higher temperature than chlorates and the decomposition temperature is in the following order: $\mathrm{Fe}<\mathrm{Mg}<\mathrm{Ca}<\mathrm{Na}<\mathrm{K}$. Iron-bearing phases present in martian surface materials can decrease the thermal decomposition temperature of oxychlorines and consume evolved $\mathrm{O}_{2}$. Water-evolving phases (e.g., phyllosilicates) can react with chlorides (original or from oxychlorine decomposition) and cause high-temperature $\left(>600^{\circ} \mathrm{C}\right) \mathrm{HCl}$ releases. Although it is still not possible to identify the type of oxychlorine using SAM-EGA data, it is possible to constrain which species may be present in a sample. Constraining the speciation of oxychlorines in Gale crater samples can provide a more complete understanding of past aqueous and diagenetic processes, the chlorine cycle on Mars, and past geochemical conditions. Additionally, the presence of oxychlorines in Gale crater has implications for interpreting past and present habitability, the detection of organics by thermal analysis, and preparing for future human exploration of Mars.

Author Contributions: This review paper summarizes many laboratory studies. All co-authors were involved with at least one of the following in the individual projects reviewed in this paper: conceptualization, methodology, software, validation, formal analysis, investigation, supervision, project administration, data curation, and funding acquisition. Resources, including mineral samples, were provided by R.M. Original draft preparation and visualization was done by J.C.; B.S.; D.M.; J.E.; D.G.; M.-P.Z.; J.M.-T.; V.T.; P.D.A.J.; E.R.; A.M.; R.M.; P.M. and S.J.R. were involved with the editing of this paper. All authors have read and agreed to the published version of the manuscript.

Funding: The research reviewed in this paper was funded by the Mars Science Laboratory (MSL) project office. M.-P.Z. acknowledges funding from the Ministerio de Ciencia e Innovación (ref. PID2019-104205GB-C21).

Data Availability Statement: SAM data are publicly available through the NASA Planetary Data System at: http://pds-geosciences.wustl.edu/missions/msl/sam.htm, which was updated in March 2021. See references for the original research articles that contain the data reviewed in this paper.

Acknowledgments: The authors are grateful to the engineers and scientists of the MSL Curiosity team, who have made the mission possible and the reported data available. The authors would also like to thank the two anonymous reviewers who provided careful reviews that increased the quality of this manuscript. The authors would like to remember and recognize the contributions of Rafael Navarro-González, a dedicated SAM and HABIT team member who passed away on 28 January 2021. Navarro-González, who was a distinguished researcher, conducted laboratory experiments that demonstrated that chloromethanes could form through a reaction between perchlorates and organics during sample heating, which greatly advanced our understanding of perchlorates and organic detection on Mars. 
Conflicts of Interest: The authors declare no conflict of interest. The funders had no role in the design of the study; in the collection, analyses, or interpretation of data; in the writing of the manuscript, or in the decision to publish the results.

\section{References}

1. Grant, J.A.; Wilson, S.A.; Mangold, N.; Calef, F.; Grotzinger, J.P. The timing of alluvial activity in Gale crater, Mars. Geophys. Res. Lett. 2014, 41, 1142-1148. [CrossRef]

2. Wray, J.J. Gale crater: The Mars Science Laboratory/Curiosity Rover Landing Site. Int. J. Astrobiol. 2013, 12, 25-38. [CrossRef]

3. Grotzinger, J.P.; Crisp, J.A.; Vasavada, A.R.; Team, M.S. Curiosity's Mission of Exploration at Gale Crater, Mars. Elements 2015, 11, 19-26. [CrossRef]

4. Dasgupta, P.K.; Martinelango, P.K.; Jackson, W.A.; Anderson, T.A.; Tian, K.; Tock, R.W.; Rajagopalan, S. The origin of naturally occurring perchlorate: The role of atmospheric processes. Environ. Sci. Technol. 2005, 39, 1569-1575. [CrossRef]

5. Jackson, W.A.; Bohlke, J.K.; Gu, B.H.; Hatzinger, P.B.; Sturchio, N.C. Isotopic Composition and Origin of Indigenous Natural Perchlorate and Co-Occurring Nitrate in the Southwestern United States. Environ. Sci. Technol. 2010, 44, 9597. [CrossRef]

6. DasGupta, P.K.; Dyke, J.V.; Kirk, A.B.; Jackson, W.A. Perchlorate in the United States. Analysis of relative source contributions to the food chain. Environ. Sci. Technol. 2006, 40, 6608-6614. [CrossRef]

7. Catling, D.C.; Claire, M.W.; Zahnle, K.J.; Quinn, R.C.; Clark, B.C.; Hecht, M.H.; Kounaves, S. Atmospheric origins of perchlorate on Mars and in the Atacama. J. Geophys. Res.-Planet. 2010, 115. [CrossRef]

8. Kounaves, S.P.; Stroble, S.T.; Anderson, R.M.; Moore, Q.; Catling, D.C.; Douglas, S.; McKay, C.P.; Ming, D.W.; Smith, P.H.; Tamppari, L.K.; et al. Discovery of Natural Perchlorate in the Antarctic Dry Valleys and Its Global Implications. Environ. Sci. Technol. 2010, 44, 2360-2364. [CrossRef] [PubMed]

9. Jackson, W.A.; Davila, A.F.; Estrada, N.; Lyons, W.B.; Coates, J.D.; Priscu, J.C. Perchlorate and chlorate biogeochemistry in ice-covered lakes of the McMurdo Dry Valleys, Antarctica. Geochim. Cosmochim. Acta 2012, 98, 19-30. [CrossRef]

10. Jackson, W.A.; Bohlke, J.K.; Andraski, B.J.; Fahlquist, L.; Bexfield, L.; Eckardt, F.D.; Gates, J.B.; Davila, A.F.; McKay, C.P.; Rao, B.; et al. Global patterns and environmental controls of perchlorate and nitrate co-occurrence in arid and semi-arid environments. Geochim. Cosmochim. Acta 2015, 164, 502-522. [CrossRef]

11. Ericksen, G.E. Geology and Origin of Chilean Nitrate Deposits; 1981. Available online: https://pubs.er.usgs.gov/publication/ pp1188 (accessed on 29 April 2021).

12. Rao, B.; Hatzinger, P.B.; Bohlke, J.K.; Sturchio, N.C.; Andraski, B.J.; Eckardt, F.D.; Jackson, W.A. Natural Chlorate in the Environment: Application of a New IC-ESI/MS/MS Method with a $\left(\mathrm{ClO}_{3}{ }^{-}\right)-\mathrm{O}-18$ Internal Standard. Environ. Sci. Technol. 2010, 44, 8429-8434. [CrossRef] [PubMed]

13. Hecht, M.H.; Kounaves, S.P.; Quinn, R.C.; West, S.J.; Young, S.M.M.; Ming, D.W.; Catling, D.C.; Clark, B.C.; Boynton, W.V.; Hoffman, J.; et al. Detection of Perchlorate and the Soluble Chemistry of Martian Soil at the Phoenix Lander Site. Science 2009, 325, 64-67. [CrossRef]

14. Hanley, J.; Chevrier, V.F.; Berget, D.J.; Adams, R.D. Chlorate salts and solutions on Mars. Geophys. Res. Lett. 2012, 39. [CrossRef]

15. Kounaves, S.P.; Chaniotakis, N.A.; Chevrier, V.F.; Carrier, B.L.; Folds, K.E.; Hansen, V.M.; McElhoney, K.M.; O’Neil, G.D.; Weber, A.W. Identification of the perchlorate parent salts at the Phoenix Mars landing site and possible implications. Icarus 2014, 232, 226-231. [CrossRef]

16. Boynton, W.V.; Bailey, S.H.; Hamara, D.K.; Williams, M.S.; Bode, R.C.; Fitzgibbon, M.R.; Ko, W.J.; Ward, M.G.; Sridhar, K.R.; Blanchard, J.A.; et al. Thermal and Evolved Gas Analyzer: Part of the Mars Volatile and Climate Surveyor integrated payload. J. Geophys. Res.-Planet. 2001, 106, 17683-17698. [CrossRef]

17. Hoffman, J.H.; Chaney, R.C.; Hammack, H. Phoenix Mars Mission-The Thermal Evolved Gas Analyzer. J. Am. Soc. Mass. Spectr. 2008, 19, 1377-1383. [CrossRef]

18. Navarro-Gonzalez, R.; Vargas, E.; de la Rosa, J.; Raga, A.C.; McKay, C.P. Reanalysis of the Viking results suggests perchlorate and organics at midlatitudes on Mars. J. Geophys. Res.-Planet. 2010, 115. [CrossRef]

19. Biemann, K.; Oro, J.; Toulmin, P.; Orgel, L.E.; Nier, A.O.; Anderson, D.M.; Simmonds, P.G.; Flory, D.; Diaz, V.; Rushneck, D.R.; et al. The search for organic substances and inorganic volatile Compounds in the surface of Mars. J. Geophys. Res.-Planet. 1977, 82, 4641-4658. [CrossRef]

20. Biemann, K.; Owen, T.; Rushneck, D.R.; Lafleur, A.L.; Howarth, D.W. Atmosphere of Mars near-Surface-Isotope Ratios and Upper Limits on Noble-Gases. Science 1976, 194, 76-78. [CrossRef]

21. Biemann, K. Composition of Lower Atmosphere and Search for Organic-Compounds in Surface of Mars. Abstr. Pap. Am. Chem. Soc 1977, 173, 57-57.

22. Mahaffy, P.R.; Webster, C.R.; Cabane, M.; Conrad, P.G.; Coll, P.; Atreya, S.K.; Arvey, R.; Barciniak, M.; Benna, M.; Bleacher, L.; et al. The Sample Analysis at Mars Investigation and Instrument Suite. Space Sci. Rev. 2012, 170, 401-478. [CrossRef]

23. Fraeman, A.A.; Edgar, L.A.; Rampe, E.B.; Thompson, L.M.; Frydenvang, J.; Fedo, C.M.; Catalano, J.G.; Dietrich, W.E.; Gabriel, T.S.J.; Vasavada, A.R.; et al. Evidence for a Diagenetic Origin of Vera Rubin Ridge, Gale Crater, Mars: Summary and Synthesis of Curiosity's Exploration Campaign. J. Geophys. Res.-Planet. 2020, 125. [CrossRef]

24. Leshin, L.A.; Mahaffy, P.R.; Webster, C.R.; Cabane, M.; Coll, P.; Conrad, P.G.; Archer, P.D.; Atreya, S.K.; Brunner, A.E.; Buch, A.; et al. Volatile, Isotope, and Organic Analysis of Martian Fines with the Mars Curiosity Rover. Science 2013, 341. [CrossRef] 
25. Glavin, D.P.; Freissinet, C.; Miller, K.E.; Eigenbrode, J.L.; Brunner, A.E.; Buch, A.; Sutter, B.; Archer, P.D.; Atreya, S.K.; Brinckerhoff, W.B.; et al. Evidence for perchlorates and the origin of chlorinated hydrocarbons detected by SAM at the Rocknest aeolian deposit in Gale Crater. J. Geophys. Res.-Planet. 2013, 118, 1955-1973. [CrossRef]

26. Sutter, B.; McAdam, A.C.; Mahaffy, P.R.; Ming, D.W.; Edgett, K.S.; Rampe, E.B.; Eigenbrode, J.L.; Franz, H.B.; Freissinet, C.; Grotzinger, J.P.; et al. Evolved gas analyses of sedimentary rocks and eolian sediment in Gale Crater, Mars: Results of the Curiosity rover's sample analysis at Mars instrument from Yellowknife Bay to the Namib Dune. J. Geophys. Res.-Planet. 2017, 122, 2574-2609. [CrossRef]

27. Archer, P.D.; Franz, H.B.; Sutter, B.; Arevalo, R.D.; Coll, P.; Eigenbrode, J.L.; Glavin, D.P.; Jones, J.J.; Leshin, L.A.; Mahaffy, P.R.; et al. Abundances and implications of volatile-bearing species from evolved gas analysis of the Rocknest aeolian deposit, Gale Crater, Mars. J. Geophys. Res.-Planet. 2014, 119, 237-254. [CrossRef]

28. Sutter, B.; McAdam, A.; Ming, D.W.; Fedo, C.; House, C.H.; Navarro-González, R.; Eigenbrode, J.L.; Mahaffy, P.R. Evolved gas and X-ray diffraction analyses of sedimentary rocks in Gale Crater, Mars: Results from the Vera Rubin Ridge to the Glen Torridon Clay Unit. In Proceedings of the American Geophysical Union Conference, San Francisco, CA, USA, 9-13 December 2019.

29. Clark, J.V.; Sutter, B.; McAdam, A.C.; Rampe, E.B.; Archer, P.D.; Ming, D.W.; Navarro-Gonzalez, R.; Mahaffy, P.; Lapen, T.J. High-Temperature $\mathrm{HCl}$ Evolutions From Mixtures of Perchlorates and Chlorides With Water-Bearing Phases: Implications for the SAM Instrument in Gale Crater, Mars. J. Geophys. Res.-Planet. 2020, 125. [CrossRef]

30. McAdam, A.C.; Sutter, B.; Archer, P.D.; Franz, H.B.; Wong, G.M.; Lewis, J.M.T.; Eigenbrode, J.L.; Stern, J.C.; Knudson, C.A.; Clark, J.V.; et al. Constraints on the Mineralogy and Geochemistry of Vera Rubin Ridge, Gale Crater, Mars, From Mars Science Laboratory Sample Analysis at Mars Evolved Gas Analyses. J. Geophys. Res.-Planet. 2020, 125. [CrossRef]

31. Hogancamp, J.V.; Sutter, B.; Morris, R.V.; Archer, P.D.; Ming, D.W.; Rampe, E.B.; Mahaffy, P.; Navarro-Gonzalez, R. Chlorate/FeBearing Phase Mixtures as a Possible Source of Oxygen and Chlorine Detected by the Sample Analysis at Mars Instrument in Gale Crater, Mars. J. Geophys. Res.-Planet. 2018, 123, 2920-2938. [CrossRef]

32. Farley, K.A.; Martin, P.; Archer, P.D.; Atreya, S.K.; Conrad, P.G.; Eigenbrode, J.L.; Fairen, A.G.; Franz, H.B.; Freissinet, C.; Glavin, D.P.; et al. Light and variable Cl-37/Cl-35 ratios in rocks from Gale Crater, Mars: Possible signature of perchlorate. Earth Planet. Sci. Lett. 2016, 438, 14-24. [CrossRef]

33. Desaulniers, D.E.; Kaufmann, R.S.; Cherry, J.A.; Bentley, H.W. Cl-37-Cl-35 Variations in a Diffusion-Controlled Groundwater System. Geochim. Cosmochim. Acta 1986, 50, 1757-1764. [CrossRef]

34. Eggenkamp, H.G.M.; Kreulen, R.; vanGroos, A.F.K. Chlorine stable isotope fractionation in evaporites. Geochim. Cosmochim. Acta 1995, 59, 5169-5175. [CrossRef]

35. Selverstone, J.; Sharp, Z.D. Chlorine isotope behavior during prograde metamorphism of sedimentary rocks. Earth Planet. Sci. Lett. 2015, 417, 120-131. [CrossRef]

36. Bohlke, J.K.; Sturchio, N.C.; Gu, B.H.; Horita, J.; Brown, G.M.; Jackson, W.A.; Batista, J.; Hatzinger, P.B. Perchlorate isotope forensics. Anal. Chem. 2005, 77, 7838-7842. [CrossRef] [PubMed]

37. Clark, J.V.; Sutter, B.; McAdam, A.C.; Archer, P.D.; Rampe, E.B.; Ming, D.W.; Navarro-González, R.; Mahaffy, P.R. Hightemperature hydrogen chloride releases from mixtures of sodium chloride with sulfates: Implications for the chlorine-mineralogy as determined by the Sample Analysis at Mars instrument on the Curiosity rover in Gale crater, Mars. In Proceedings of the Lunar and Planetary Science Conference, The Woodlands, TX, USA, 16-20 March 2020.

38. Ojha, L.; Wilhelm, M.B.; Murchie, S.L.; McEwen, A.S.; Wray, J.J.; Hanley, J.; Masse, M.; Chojnacki, M. Spectral evidence for hydrated salts in recurring slope lineae on Mars. Nat. Geosci. 2015, 8, 829-832. [CrossRef]

39. McEwen, A.S.; Ojha, L.; Dundas, C.M.; Mattson, S.S.; Byrne, S.; Wray, J.J.; Cull, S.C.; Murchie, S.L.; Thomas, N.; Gulick, V.C. Seasonal Flows on Warm Martian Slopes. Science 2011, 333, 740-743. [CrossRef]

40. Leask, E.K.; Ehlmann, B.L.; Dundar, M.M.; Murchie, S.L.; Seelos, F.P. Challenges in the Search for Perchlorate and Other Hydrated Minerals With 2.1- $\mu \mathrm{m}$ Absorptions on Mars. Geophys. Res. Lett. 2018, 45, 180-189. [CrossRef]

41. Murphy, C.; Hanley, J.; Horgan, B.; Carmack, R. Detection of Chlorine Salt Spectral Features in Columbus Crater, Mars. In Proceedings of the 2020 Lunar and Planetary Science Conference (LPSC-2020), The Woodlands, TX, USA, 16-20 March 2020.

42. Kounaves, S.P.; Carrier, B.L.; O'Neil, G.D.; Stroble, S.T.; Claire, M.W. Evidence of martian perchlorate, chlorate, and nitrate in Mars meteorite EETA79001: Implications for oxidants and organics. Icarus 2014, 229, 206-213. [CrossRef]

43. Jaramillo, E.A.; Royle, S.H.; Claire, M.W.; Kounaves, S.P.; Sephton, M.A. Indigenous Organic-Oxidized Fluid Interactions in the Tissint Mars Meteorite. Geophys. Res. Lett. 2019, 46, 3090-3098. [CrossRef]

44. Steele, A.; Benning, L.G.; Wirth, R.; Siljestrom, S.; Fries, M.D.; Hauri, E.; Conrad, P.G.; Rogers, K.; Eigenbrode, J.L.; Schreiber, A.; et al. Organic synthesis on Mars by electrochemical reduction of $\mathrm{CO}_{2}$. Sci. Adv. 2018, 4. [CrossRef]

45. Marvin, G.G.; Woolaver, L.B. Thermal Decomposition of Perchlorates. Ind. Eng. Chem. 1945, 17, 474-476. [CrossRef]

46. Acheson, R.J.; Jacobs, P.W.M. The thermal decomposition of magnesium perchlorate and of ammonium perchlorate and magnesium perchlorate mixtures. J. Phys. Chem. 1970, 7, 281-288. [CrossRef]

47. Devlin, D.J.; Herley, P.J. Thermal-Decomposition and Dehydration of Magnesium Perchlorate Hexahydrate. Thermochimica Acta 1986, 104, 159-178. [CrossRef]

48. Cannon, K.M.; Sutter, B.; Ming, D.W.; Boynton, W.V.; Quinn, R. Perchlorate induced low temperature carbonate decomposition in the Mars Phoenix Thermal and Evolved Gas Analyzer (TEGA). Geophys. Res. Lett. 2012, 39. [CrossRef] 
49. Rudloff, W.K.; Freeman, E.S. The catalytic effect of metal oxides on thermal-decomposition reactions. I. The mechanism of the molten-phase thermal decomposition of potassium chlorate and of potassium chlorate in mixtures of potassium chloride and potassium perchlorate. J. Phys. Chem. 1968, 73, 1209-1215. [CrossRef]

50. Devlin, D.J.; Herley, P.J. Thermal-Decomposition and Dehydration of Sodium-Perchlorate Monohydrate. React. Solid 1987, 3 , 75-84. [CrossRef]

51. Bishop, J.L.; Quinn, R.; Dyar, M.D. Spectral and thermal properties of perchlorate salts and implications for Mars. Am. Mineral. 2014, 99, 1580-1592. [CrossRef]

52. Sutter, B.; Heil, E.; Morris, R.V.; Archer, P.D.; Ming, D.W.; Niles, P.B.; Eigenbrode, J.L.; Franz, H. The investigation of perchlorate/iron phase mixtures as a possible source of oxygen detected by the Sample Analysis at Mars (SAM) instrument in Gale Crater, Mars. In Proceedings of the 46th Lunar and Planetary Science Conference, The Woodlands, TX, USA, 16-20 March 2015.

53. Sutter, B.; Archer, P.D.; Ming, D.W.; Niles, P.B.; Eigenbrode, J.L.; Franz, H.; Glavin, D.P.; McAdam, A.C. The investigation of chlorates as a possible source of oxygen and chlorine detected by the Sample Analysis at Mars (SAM) instrument in Gale crater, Mars. In Proceedings of the 45th Lunar and Planetary Science Conference, The Woodlands, TX, USA, 17-21 March 2014.

54. Ming, D.W.; Archer, P.D.; Glavin, D.P.; Eigenbrode, J.L.; Franz, H.B.; Sutter, B.; Brunner, A.E.; Stern, J.C.; Freissinet, C.; McAdam, A.C.; et al. Volatile and Organic Compositions of Sedimentary Rocks in Yellowknife Bay, Gale Crater, Mars. Science 2014, 343. [CrossRef]

55. Wydeven, T. Catalytic Decomposition of Sodium Chlorate. J. Catal. 1970, 19, 162-171. [CrossRef]

56. Pourmortazavi, S.M.; Hajimirsadeghi, S.S.; Hosseini, S.G. Characterization of the aluminum/potassium chlorate mixtures by simultaneous TG-DTA. J. Therm Anal. Calorim. 2006, 84, 557-561. [CrossRef]

57. Dong, X.F.; Yan, Q.L.; Zhang, X.H.; Cao, D.L.; Xuan, C.L. Effect of potassium chlorate on thermal decomposition of cyclotrimethylenetrinitramine (RDX). J. Anal. Appl. Pyrol. 2012, 93, 160-164. [CrossRef]

58. Sutter, B.; Heil, E.; Archer, P.D.; Ming, D.W.; Eigenbrode, J.L.; Franz, H.B.; Glavin, D.P.; McAdam, A.C.; Mahaffy, P.R.; Niles, P.B.; et al. The investigation of magnesium perchlorate/iron phase mineral mixtures as a possible source of oxygen and chlorine as detected by the sample analysis at Mars (SAM) instrument in Gale crater, Mars. In Proceedings of the Eighth International Conference on Mars, Pasadena, CA, USA, 14-18 July 2014.

59. Zhang, Y.C.; Kshirsagar, G.; Ellison, J.E.; Cannon, J.C. Catalytic and Inhibiting Effects of Barium Peroxide and Hydroxide on the Decomposition of Sodium-Chlorate. Thermochim. Acta 1995, 261, 119-124. [CrossRef]

60. Zhang, Y.C.; Kshirsagar, G.; Ellison, J.E.; Cannon, J.C. Catalytic effects of metal oxides on the decomposition of Potassium perchlorate. Thermochim. Acta 1996, 278, 119-127. [CrossRef]

61. Vaniman, D.T.; Bish, D.L.; Ming, D.W.; Bristow, T.F.; Morris, R.V.; Blake, D.F.; Chipera, S.J.; Morrison, S.M.; Treiman, A.H.; Rampe, E.B.; et al. Mineralogy of a Mudstone at Yellowknife Bay, Gale Crater, Mars. Science 2014, 343. [CrossRef] [PubMed]

62. Treiman, A.H.; Bish, D.L.; Vaniman, D.T.; Chipera, S.J.; Blake, D.F.; Ming, D.W.; Morris, R.V.; Bristow, T.F.; Morrison, S.M.; Baker, M.B.; et al. Mineralogy, provenance, and diagenesis of a potassic basaltic sandstone on Mars: CheMin X-ray diffraction of the Windjana sample (Kimberley area, Gale Crater). J. Geophys. Res.-Planet. 2016, 121, 75-106. [CrossRef]

63. Achilles, C.N.; Downs, R.T.; Ming, D.W.; Rampe, E.B.; Morris, R.V.; Treiman, A.H.; Morrison, S.M.; Blake, D.F.; Vaniman, D.T.; Ewing, R.C.; et al. Mineralogy of an active eolian sediment from the Namib dune, Gale crater, Mars. J. Geophys. Res.-Planet. 2017, 122, 2344-2361. [CrossRef]

64. Yen, A.S.; Ming, D.W.; Vaniman, D.T.; Gellert, R.; Blake, D.F.; Morris, R.V.; Morrison, S.M.; Bristow, T.F.; Chipera, S.J.; Edgett, K.S.; et al. Multiple stages of aqueous alteration along fractures in mudstone and sandstone strata in Gale Crater, Mars. Earth Planet. ScI. Lett. 2017, 471, 186-198. [CrossRef]

65. Morris, R.V.; Golden, D.C.; Ming, D.W.; Shelfer, T.D.; Jorgensen, L.C.; Bell III, J.F.; Graff, T.F.; Mertzman, S.A. Phyllosilicate-poor palagonite dust from Mauna Kea Volcano (Hawaii): A mineralogical analogue for magnetic Martian dust? J. Geophys. Res.-Planet. 2001, 106, 5057-5083. [CrossRef]

66. Peretyazhko, T.S.; Ralston, S.J.; Sutter, B.; Ming, D.W. Evidence for Adsorption of Chlorine Species on Iron (III) (Hydr)oxides in the Sheepbed Mudstone, Gale Crater, Mars. J. Geophys. Res.-Planet. 2020, 125. [CrossRef]

67. Webb, P.A.; Orr, C. Analytical Methods in Fine Particle Technology; Micromeritics Instrument Corporation: Norcross, GA, USA, 1997.

68. Eggleston, C.M.; Stack, A.G.; Rosso, K.M.; Bice, A.M. Adatom Fe(III) on the hematite surface: Observation of a key reactive surface species. Geochem. Trans. 2004, 5, 33-40. [CrossRef]

69. Warschkow, O.; Ellis, D.E.; Hwang, J.H.; Mansourian-Hadavi, N.; Mason, T.O. Defects and charge transport near the hematite (0001) surface: An atomistic study of oxygen vacancies. J. Am. Ceram. Soc. 2002, 85, 213-220. [CrossRef]

70. Uchida, S.; Kamo, H.; Kubota, H.; Kanaya, K. Reaction-Kinetics of Formation of Hcl in Municipal Refuse Incinerators. Ind. Eng. Chem. Proc. Dd 1983, 22, 144-149. [CrossRef]

71. Fraisslera, G.; Jöllera, M.; Brunnera, T.; Obernbergera, I. Influence of dry and humid gaseous atmosphere on the thermal decomposition of calcium chloride and its impact on the remove of heavy metals by chlorination. Chem. Eng. Process. Process. Intensif. 2009, 48, 380-388. [CrossRef]

72. Blake, D.F.; Morris, R.V.; Kocurek, G.; Morrison, S.M.; Downs, R.T.; Bish, D.; Ming, D.W.; Edgett, K.S.; Rubin, D.; Goetz, W.; et al. Curiosity at Gale Crater, Mars: Characterization and Analysis of the Rocknest Sand Shadow. Science 2013, 341. [CrossRef] [PubMed] 
73. Rampe, E.B.; Ming, D.W.; Blake, D.F.; Bristow, T.F.; Chipera, S.J.; Grotzinger, J.P.; Morris, R.V.; Morrison, S.M.; Vaniman, D.T.; Yen, A.S.; et al. Mineralogy of an ancient lacustrine mudstone succession from the Murray formation, Gale crater, Mars. Earth Planet. ScI. Lett. 2017, 471, 172-185. [CrossRef]

74. Rampe, E.B.; Bristow, T.F.; Blake, D.F.; Vaniman, D.T.; Morris, R.V.; Ming, D.W.; Achilles, C.N.; Chipera, S.J. The mineralogical record of ancient fluvio-lacustrine environments in Gale crater as measured by the MSL CheMin instrument. LPI Contrib. 2019, 2089,6054

75. Robinson, H. Improvements in the Manufacture of Sulphate of Soda. 1872. Available online: https:/ /worldwide.espacenet.com/ publicationDetails / biblio?FT=D\&date=19180411\&DB=EPODOC\&CC=GB\&NR=114501A (accessed on 20 January 2021).

76. Henriksson, M.; Warnqvist, B. Kinetics of Formation of $\mathrm{Hcl}(\mathrm{G})$ by the Reaction between $\mathrm{Nacl}(\mathrm{S})$ and $\mathrm{SO}_{2}, \mathrm{O}_{2}$, and $\mathrm{H}_{2} \mathrm{O}(\mathrm{G})$. Ind Eng. Chem. Proc. Dd 1979, 18, 249-254. [CrossRef]

77. Clark, J.V.; Archer, P.D.; Gruener, J.E.; Ming, D.W.; Tu, V.M.; Niles, P.B.; Mertzman, S.A. JSC-Rocknest: A large-scale Mojave Mars Simulant (MMS) based soil simulant for in-situ resource utilization water-extraction studies. Icarus 2020, 351. [CrossRef]

78. Kang, N.G.; Anderson, T.A.; Jackson, W.A. Photochemical formation of perchlorate from aqueous oxychlorine anions. Anal. Chim. Acta 2006, 567, 48-56. [CrossRef]

79. Quinn, R.C.; Martucci, H.F.H.; Miller, S.R.; Bryson, C.E.; Grunthaner, F.J.; Grunthaner, P.J. Perchlorate Radiolysis on Mars and the Origin of Martian Soil Reactivity. Astrobiology 2013, 13, 515-520. [CrossRef]

80. Trainer, M.G.; Wong, M.H.; McConnochie, T.H.; Franz, H.B.; Atreya, S.K.; Conrad, P.G.; Lefevre, F.; Mahaffy, P.R.; Malespin, C.A.; Manning, H.L.; et al. Seasonal Variations in Atmospheric Composition as Measured in Gale Crater, Mars. J. Geophys. Res.-Planet. 2019, 124, 3000-3024. [CrossRef]

81. Korablev, O.; Olsen, K.; Trokhimovskiy, A.; Lefevre, F.; Montmessin, F.; Fedorova, A.; Toplis, M.; Alday, J.; Belyaev, D.; Abdenour, I.; et al. Transient $\mathrm{HCl}$ in the atmosphere of Mars. Sci. Adv. 2021, 7, eabe4386. [CrossRef] [PubMed]

82. Lide, D. CRC Handbook of Chemistry and Physics; CRC Press: Boca Raton, FL, USA, 2005.

83. Noble, L.F.; Mansfield, G.R. Nitrate Deposits in the Amargosa Region. Southeastern California; United States Geological Survey: Reston, VA, USA, 1922; pp. 1-99.

84. Ericksen, G.E. The Chilean Nitrate Deposits. Am. Sci. 1983, 71, 366-374.

85. Ericksen, G.E.; Hosterman, J.W.; Stamand, P. Chemistry, Mineralogy and Origin of the Clay-Hill Nitrate Deposits, Amargosa River Valley, Death-Valley Region, California, USA. Chem. Geol. 1988, 67, 85-102. [CrossRef]

86. Prellwitz, J. A Characterization of Hyper-Arid Soils in the Baquedano Valley of the Atacama Desert, Northern Chile; Miami University: Miami, FL, USA, 2007.

87. Lybrand, R.A.; Bockheim, J.G.; Ge, W.S.; Graham, R.C.; Hlohowskyj, S.R.; Michalski, G.; Prellwitz, J.S.; Rech, J.A.; Wang, F.; Parker, D.R. Nitrate, perchlorate, and iodate co-occur in coastal and inland deserts on Earth. Chem. Geol. 2016, 442, 174-186. [CrossRef]

88. Logan, B.E. A Review of Chlorate- and Perchlorate-Respiring Microorganisms. Bioremediation J. 2010, 2, 69-79. [CrossRef]

89. Liebensteiner, M.G.; Oosterkamp, M.J.; Stams, A.J.M. Microbial respiration with chlorine oxyanions: Diversity and physiological and biochemical properties of chlorate- and perchlorate-reducing microorganisms. Ann. Ny Acad Sci. 2016, 1365, 59-72. [CrossRef] [PubMed]

90. Martin, F.; Saiz-Jimenez, C.; Gonzalez-Villa, F.J. The persulfate oxidation of a soil humic acid. Soil Sci. 1980, 132, 200-203. [CrossRef]

91. Cuypers, C.; Grotenhuis, T.; Nierop, K.G.J.; Franco, E.M.; de Jager, A.R.; Rulkens, W. Amorphous and condensed organic matter domains: The effect of persulfate oxidation on the composition of soil/sediment organic matter. Chemosphere 2002, 48, 919-931. [CrossRef]

92. Royle, S.H.; Oberlin, E.; Watson, J.S.; Montgomery, W.; Kounaves, S.P.; Sephton, M.A. Perchlorate-Driven Combustion of Organic Matter During Pyrolysis-Gas Chromatography-Mass Spectrometry: Implications for Organic Matter Detection on Earth and Mars. J. Geophys. Res.-Planet. 2018, 123, 1901-1909. [CrossRef]

93. Freissinet, C.; Glavin, D.P.; Mahaffy, P.R.; Miller, K.E.; Eigenbrode, J.L.; Summons, R.E.; Brunner, A.E.; Buch, A.; Szopa, C.; Archer, P.D.; et al. Organic molecules in the Sheepbed Mudstone, Gale Crater, Mars. J. Geophys. Res.-Planet. 2015, 120, 495-514. [CrossRef] [PubMed]

94. Eigenbrode, J.L.; Summons, R.E.; Steele, A.; Freissinet, C.; Millan, M.; Navarro-Gonzalez, R.; Sutter, B.; McAdam, A.C.; Franz, H.B.; Glavin, D.P.; et al. Organic matter preserved in 3-billion-year-old mudstones at Gale crater, Mars. Science 2018, 360, $1096-1100$. [CrossRef] [PubMed]

95. Szopa, C.; Freissinet, C.; Glavin, D.P.; Millan, M.; Buch, A.; Franz, H.B.; Summons, R.E.; Sumner, D.Y.; Sutter, B.; Eigenbrode, J.L.; et al. First Detections of Dichlorobenzene Isomers and Trichloromethylpropane from Organic Matter Indigenous to Mars Mudstone in Gale Crater, Mars: Results from the Sample Analysis at Mars Instrument Onboard the Curiosity Rover. Astrobiology 2020, 20, 292-306. [CrossRef] [PubMed]

96. Eigenbrode, J.L.; Ehresmann, B.; Floyd, M.; Hassler, D.M.; McAdam, A.; Pavlov, A.; Rafkin, S.; Zeitlin, C. The effects of proton ionizing radiation on organic matter in martian surface sediments. In Proceedings of the 2015 Astrobiology Science Conference, Chicago, IL, USA, 15-19 June 2015.

97. Montgomery, W.; Jaramillo, E.A.; Royle, S.H.; Kounaves, S.P.; Schulze-Makuch, D.; Sephton, M.A. Effects of Oxygen-Containing Salts on the Detection of Organic Biomarkers on Mars and in Terrestrial Analog Soils. Astrobiology 2019, 19, 711-721. [CrossRef] [PubMed] 
98. Martin-Torres, F.J.; Zorzano, M.P.; Valentin-Serrano, P.; Harri, A.M.; Genzer, M.; Kemppinen, O.; Rivera-Valentin, E.G.; Jun, I.; Wray, J.; Madsen, M.B.; et al. Transient liquid water and water activity at Gale crater on Mars. Nat. Geosci. 2015, 8, 357-361. [CrossRef]

99. Martin-Torres, J.; Zorzano, M.P.; Soria-Salinas, A.; Nazarious, M.I.; Konatham, S.; Mathanlal, T.; Ramachandran, A.V.; RamirezLuque, J.A.; Mantas-Nakhai, R. The HABIT (HabitAbility: Brine Irradiation and Temperature) environmental instrument for the ExoMars 2022 Surface Platform. Planet. Space Sci. 2020, 190. [CrossRef]

100. Schwenzer, S.P.; Bridges, J.C.; Wiens, R.C.; Conrad, P.G.; Kelley, S.P.; Leveille, R.; Mangold, N.; Martin-Torres, J.; McAdam, A.; Newsom, H.; et al. Fluids during diagenesis and sulfate vein formation in sediments at Gale crater, Mars. Meteorit Planet. Sci. 2016, 51, 2175-2202. [CrossRef]

101. Alfonso, D.; Wilson, D.; Coates, J.D.; McKay, C.P. Perchlorate on Mars: A chemical hazard and a resource for humans. Int. J. Astrobiol. 2013, 12, 321-325.

102. Ha, W.; Suarez, D.L.; Lesch, S.M. Perchlorate Uptake in Spinach As Related to Perchlorate, Nitrate, And Chloride Concentrations in Irrigation Water. Environ. Sci. Technol. 2011, 45, 9363-9371. [CrossRef]

103. Leung, A.M.; Pearce, E.N.; Braverman, L.E. Perchlorate, iodine and the thyroid. Best Pract. Res. Clin. Endocrinol. Metab. 2010, 24, 133-141. [CrossRef] 